\title{
HEAVY METAL ADSORPTION BY DEWATERED IRON-CONTAINING WASTE SLUDGE
}

\author{
ADSORPCJA METALI CIĘŻKICH \\ PRZEZ ODWODNIONY OSAD ŚCIEKOWY ZAWIERAJĄCY ŻELAZO
}

\begin{abstract}
Drinking water treatment plants produce significant amounts of waste sludge. In this study, removal of Nickel ion by use of wastewater sludge was aimed. The adsorption capability of waste sludge was optimized with varying physical parameters such as $\mathrm{pH}$, adsorbent dosage, adsorbate concentration, contact time, shaking speed and temperature. Initial concentration was set as $25 \mathrm{mg} / \mathrm{dm}^{3}$, absorbent dose was set as $0.3 \mathrm{~g} / \mathrm{cm}^{3}$, and temperature was set as $25^{\circ} \mathrm{C}$. Compliance of balance data with Langmuir, Freundlich, Temkin and D-R isotherm models was investigated. The highest $R^{2}$ values were obtained with Freundlich isotherm $\left(R^{2}=0.92-0.95\right)$. Adsorption kinetics was analysed using pseudo-first order, pseudo-second order, Weber and Morris intraparticle diffusion and Elovich kinetic models, and the system was found to be in a better compliance with pseudo-second order kinetic model. Iron sludge was used as sorbent, and accordingly total iron ion measurements were carried out to determine its possible effects on water. Additionally, SEM, EDX, FTIR spectroscopy, XRD spectrum and atomic force microscope (AFM) measurements were conducted to determine the interaction between the sorbent and metal ions, in addition to characterization of the sorbent. As indicated by research results, drinking water treatment sludge proved to be a potential adsorbent for removal of nickel(II) ions from the solution.
\end{abstract}

Keywords: waste sludge, isotherm study, iron, $\mathrm{Ni}(\mathrm{II})$ ions

\section{Introduction}

Heavy metals are nonbiodegradable wastes commonly detected in industrial wastes, therefore they should be removed from water before discharge [1]. Nickel and iron are toxic heavy metals which pose serious threats for human health. Primary sources of nickel are; electroplating, iron, steel industries, electrical engineering and electronic production, chemical industry, plastic production and coal combustion. This element belongs to second grade toxicity class and it is characterized with low mutagenic and carcinogenic attributes. Main sources of this element are metallurgy, chemical, dye industry, fabric painting and textile printing [2].

Water supply systems usually comprise a water intake, purification facilities, transit pipelines, pumping stations and storage facilities [3]. Various drinking water treatment

\footnotetext{
${ }^{1}$ Department of Environmental Engineering, Engineering Faculty, Cumhuriyet University, 58140, Sivas, Turkey, phone +90 3462191010

${ }^{2}$ Institute of Science, Cumhuriyet University, 58140, Sivas, Turkey

*Corresponding author: sayiteryildiz@gmail.com
} 
processes generate a vast amount of waste sludge around the worlds, which requires economically sustainable and environment-friendly ways of sludge removal methods [4]. Coagulation and flocculation are basic pre-treatment methods used for waste removal in wastewater treatment, and aluminum and iron salts are conventionally used for this purpose, for a long period [5]. Drinking water treatment sludge (DWTS) is referred to as aluminum, iron or polymeric sludge depending on the type of coagulant used in the treatment plant.

Sludge amount and composition is generally dependent on water quality, removal efficiency, as well as the type and dose of coagulant. Sludge amount is within the interval of $1-5 \%$ of the total amount of untreated water [6]. Sludge typically consists of the suspension of inorganic and organic materials such as silica, hydrated aluminum oxide and iron oxide [7]. Water content of wet sludge is generally higher than $80 \%$ by weight. Organic material content of dewatered sludge is around $25 \%$ and its particle size distribution is under $100 \mathrm{~mm}$ [8].

Pollutant or hazardous substance content of DWTP sludge is relatively low, which allows the use of DWTP sludge as adsorbent material. Additionally, there is still limited number of studies on DTWP sludge as adsorbent material for removal of heavy metal ions [9].

Waste sludge has been subject of various studies for degradation and reuse of sludge discharge. These studies involve the recycling and reuse of coagulants [10], the use of waste sludge as coagulant in waste water treatment [11], its use as adsorbent for removal of phosphorus [12, 13], manganese [14], fluoride [15], arsenic [16, 17], boron [18], ammonium [19], $\mathrm{Pb}$ (II), $\mathrm{Cr}(\mathrm{III}), \mathrm{Cr}(\mathrm{VI})$ [20] from aqueous solutions; its use for dewatering with waste sludge [21], in brick [22] and ceramic production [23], its use in soil amendment $[24,25]$ and cement production [26]. Reuse of sludge can be beneficial for production of a cost-efficient adsorbent for removal of heavy metal ions, in addition to reduction of solid waste amounts generated by DWTPs.

The aim of this research is to evaluate the adsorption capacity of iron-based waterworks sludge, produced by drinking water treatment plants, during the removal of $\mathrm{Ni}(\mathrm{II})$ ion from water. During the research, various experimental parameters such as the $\mathrm{pH}$ of aqueous solution, contact time, initial concentration and temperature and their effect on adsorption process were analyzed. Additionally, kinetic models (pseudo first order, pseudo second order, Elovich and intraparticle diffusion models) were evaluated in terms of their effectiveness and isotherm models (Langmuir, Freundlich, Temkin and Dubinin Radushkevich) were examined to determine their applicability. Thermodynamic feasibility of adsorption process was evaluated on the basis of thermodynamic parameters (Gibbs energy $(\Delta G)$, enthalpy $(\Delta H)$ and entropy $(\Delta S))$. As waste sludge with iron content was used as sorbent, total Fe ion measurements were performed to determine its effect on water.

Scanning electron microscope (SEM), energy dispersive X-ray analysis (EDX), Fourier transform infrared (FTIR) spectroscopy, X-ray diffraction (XRD) spectrum and atomic force microscopy (AFM) analyses were applied to determine the interaction of DWTP sludge with metal ions. Sorption experiments were performed for three times and mean values of the samples were presented. The presented data are the mean values obtained from experiments, standard error $(\leq 6 \%)$ and error bars are shown in the figures. 


\section{Material and methods}

\section{Preparation of adsorbent}

The adsorbent material was developed using the sludge generated by the sludge dewatering unit (belt press) of the drinking water treatment plant in Sivas province. In this plant, $\mathrm{FeCl}_{3}$ is used as coagulant $(800 \mathrm{~kg} / \mathrm{d})$ to remove flocculation and colloidal substances. Sludge is mainly composed of iron, iron hydroxide, clay and colloidal substances [27]. Sludge was washed with distilled water and left to drying at $105{ }^{\circ} \mathrm{C}$ for 24 hours. After cooling down at room temperature, sludge was pulverized and sieved with $1 \mathrm{~mm}$ mesh sieve. During the preparation stage, only analytical grade reagents of the highest quality were used in addition to deionized water.

\section{Reagents}

$4.050 \mathrm{~g}$ nickel chloride $\left(\mathrm{NiCl}_{2} \cdot 6 \mathrm{H}_{2} \mathrm{O}\right)$ was used so as to obtain $1000 \mathrm{mg} / \mathrm{dm}^{3}$ in $1 \mathrm{dm}^{3}$ volume, to prepare the $\mathrm{Ni}$ solution. Solutions with different concentrations were prepared by dillution of stock solution.

\section{Characterization of adsorbent}

FTIR spectrum was used to determine the frequency variations of functional groups in the absorbent. The region of most interest for chemical analysis is the mid-infrared region with the wavenumber range of 4000 to $400 \mathrm{~cm}^{-1}$ [28]. The spectra, measured in $400-4000 \mathrm{~cm}^{-1}$ interval, are given in Figure 1. FTIR peaks represent various chemical bonds in the sample that are likely to be effective in sorption activity. The peak at $3364.61 \mathrm{~cm}^{-1}$ is assigned to $-\mathrm{OH}$ polar groups. The bands $1416.80 \mathrm{~cm}^{-1}$ are assigned to aliphatic $-\mathrm{CH}_{2}$ units. The sorption peaks at $1633.78 \mathrm{~cm}^{-1}$ are assigned to aromatic $\mathrm{C}=\mathrm{O}$ and $\mathrm{C}=\mathrm{C}$ vibration indicating presence of hard carbon components. The peaks around $985.96 \mathrm{~cm}^{-1}$ correspond to aliphatic $\mathrm{C}-\mathrm{O}-\mathrm{C}$ and alcohol $-\mathrm{OH}$ representing oxygenated functional groups of cellulosic and ligneous components [29]. The band at $509.00 \mathrm{~cm}^{-1}$ may correspond to $\mathrm{SiO}-\mathrm{H}$ vibration [30]. The oxygen containing functional groups have been reported to have an important role related to the capacity of organic sorbents in heavy metal absorption [29]. Accordingly, it can be inferred that, the physical sorption of $\mathrm{Ni}^{2+}$ by DWTP sludge is related to the coulombic forces which represent the electrostatic energy arising from the interaction between the metal ions and oxygenated functional groups of the adsorbent [31].

EDX (Energy dispersive X-ray) analyses were performed for elemental analyses before and after adsorption (Fig. 2). No nickel ions were detected in EDX analyses performed prior to biosorption. Also, Ni(II) ions were detected to be adsorbed by waste sludge, after adsorption process.

SEM and AFM micrographs provide quantitative analyses. Morphological characteristics of adsorbents are commonly investigated with SEM analysis [32]. SEM micrographs of the samples are given in Figure 3. The change in the surface morphology before and after sorption can be clearly seen in the image. Prior to adsorption, sorbent surface has a rougher structure, whereas after sorption these voids are filled and the surface took on a smoother appearance. Surface roughness decreases with ion adsorption. Metal removal can be characterized with the reduced volume of specific regions and total pores after $\mathrm{Ni}(\mathrm{II})$ adsorption. 
a)

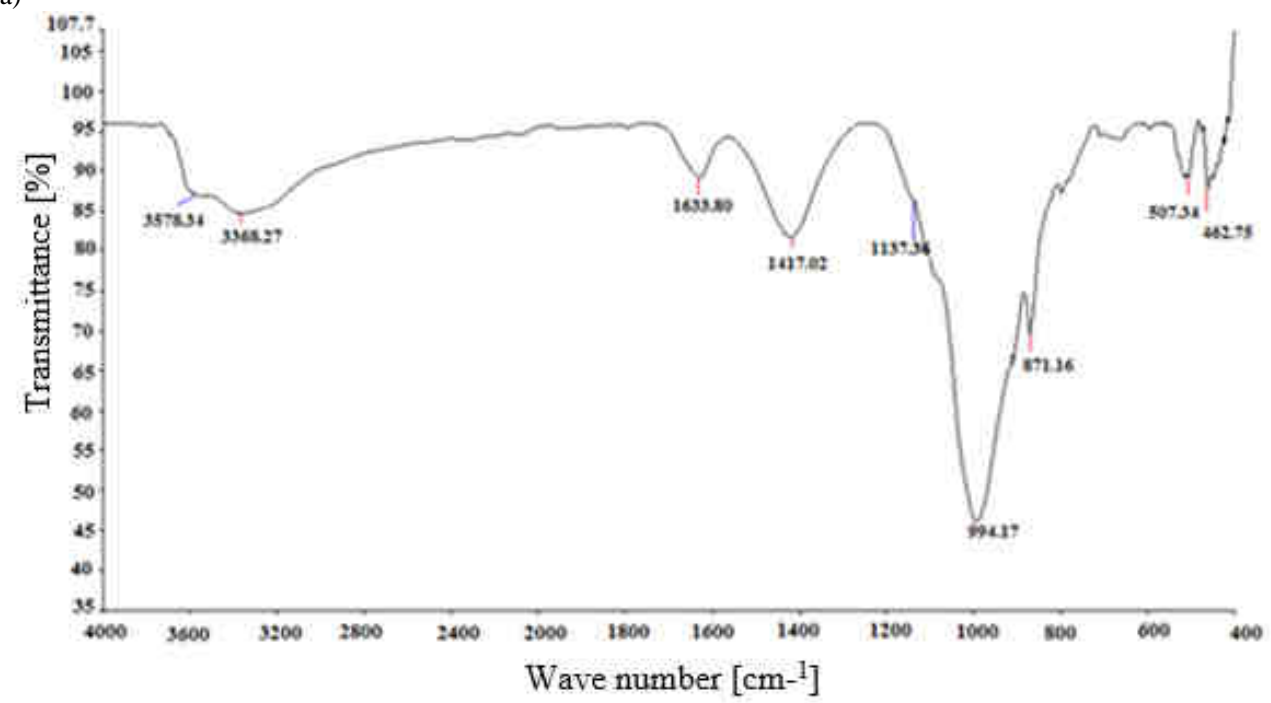

b)

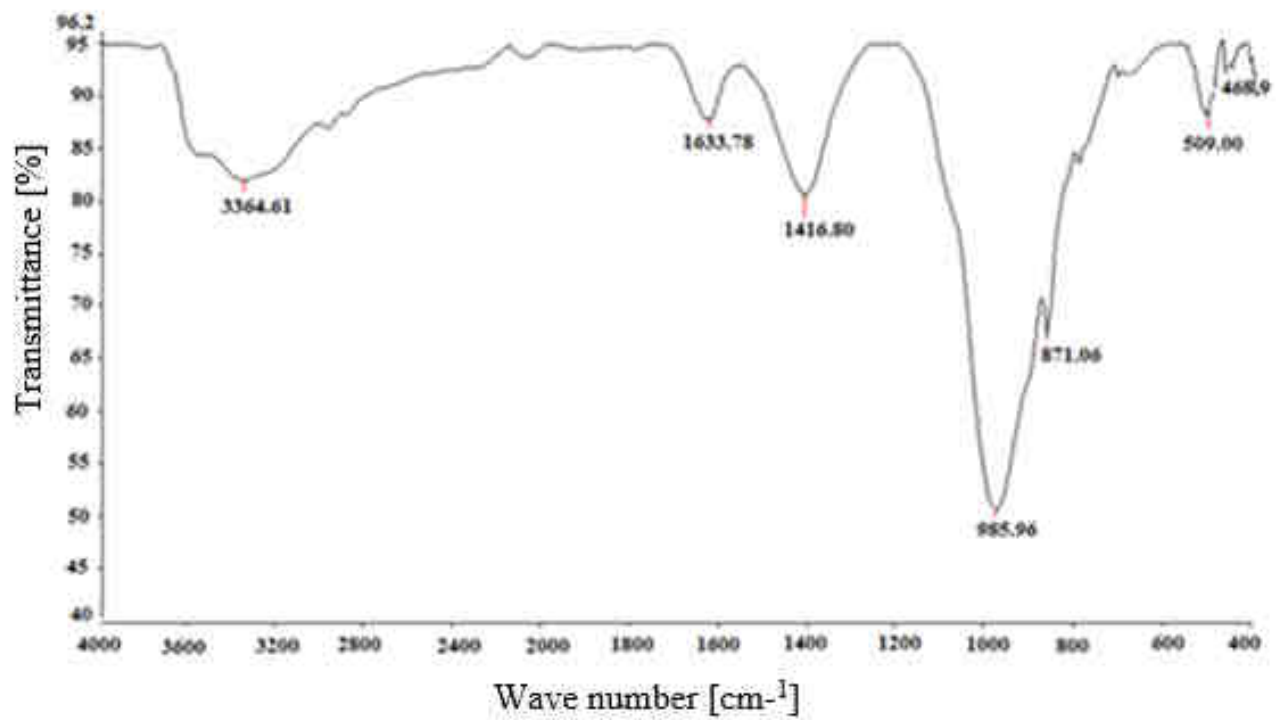

Fig. 1. FTIR spectrum: a) before and b) after adsorption 
a)

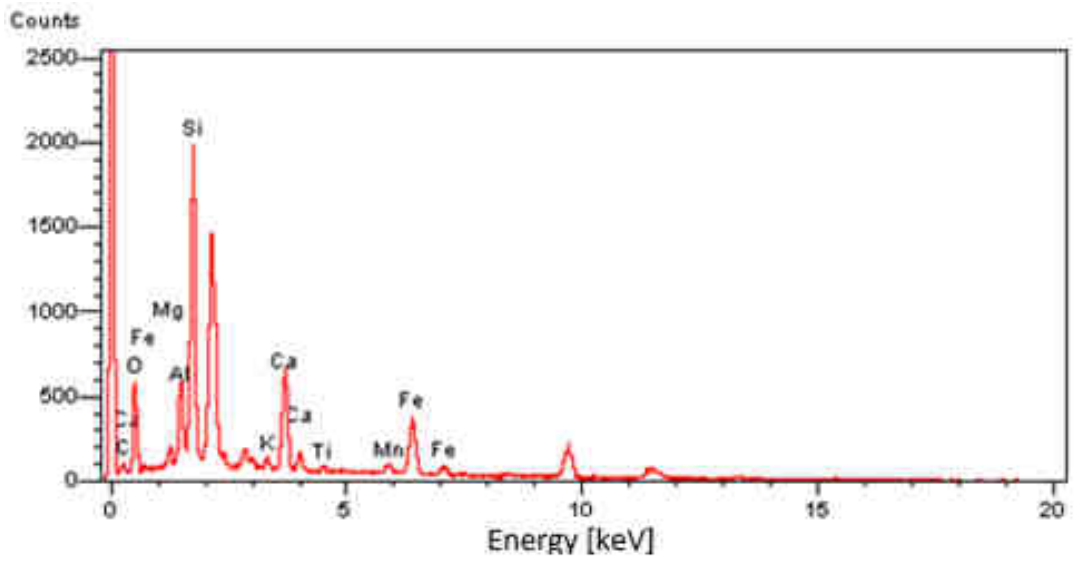

b)

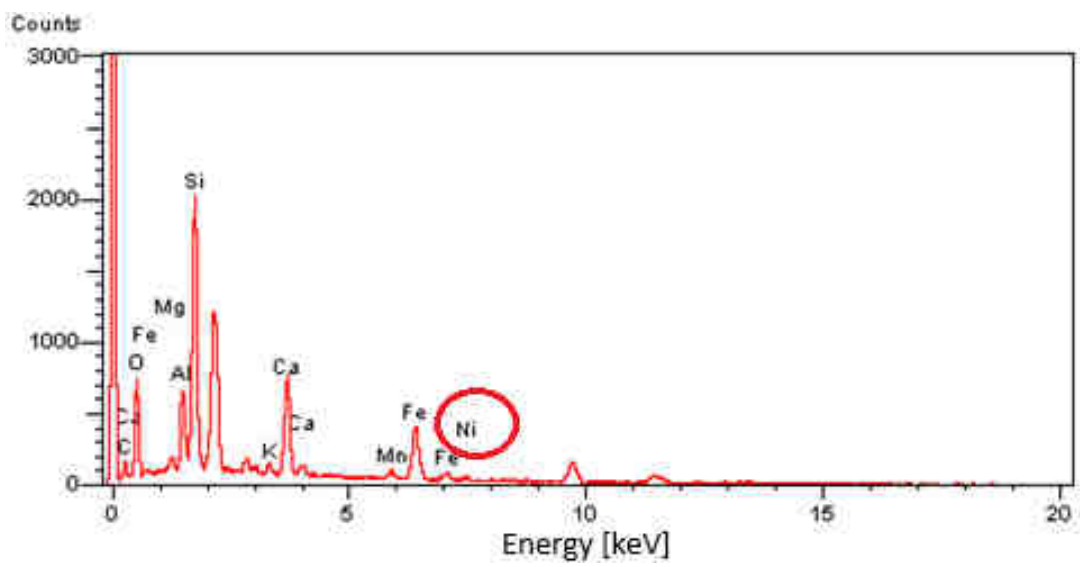

Fig. 2. EDX analysis of: a) unloaded, b) Ni(II) ions loaded DWTP sludge

a)

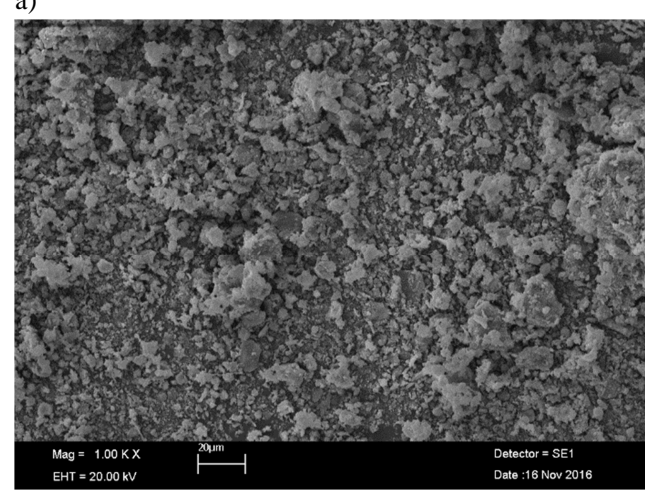

b)

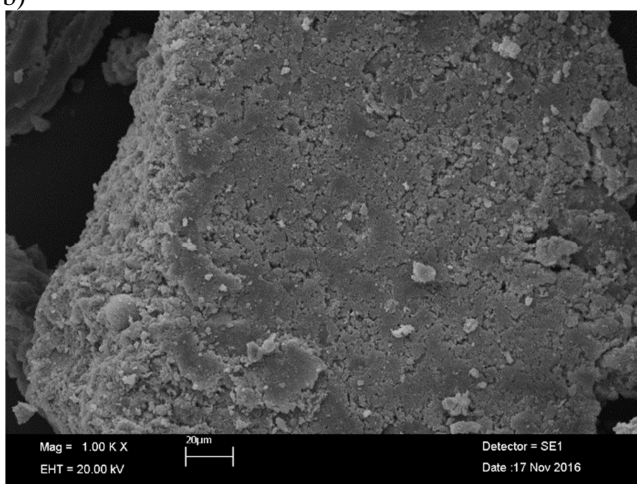

Fig. 3. SEM image of sorbent: a) before and b) after adsorption 
a)
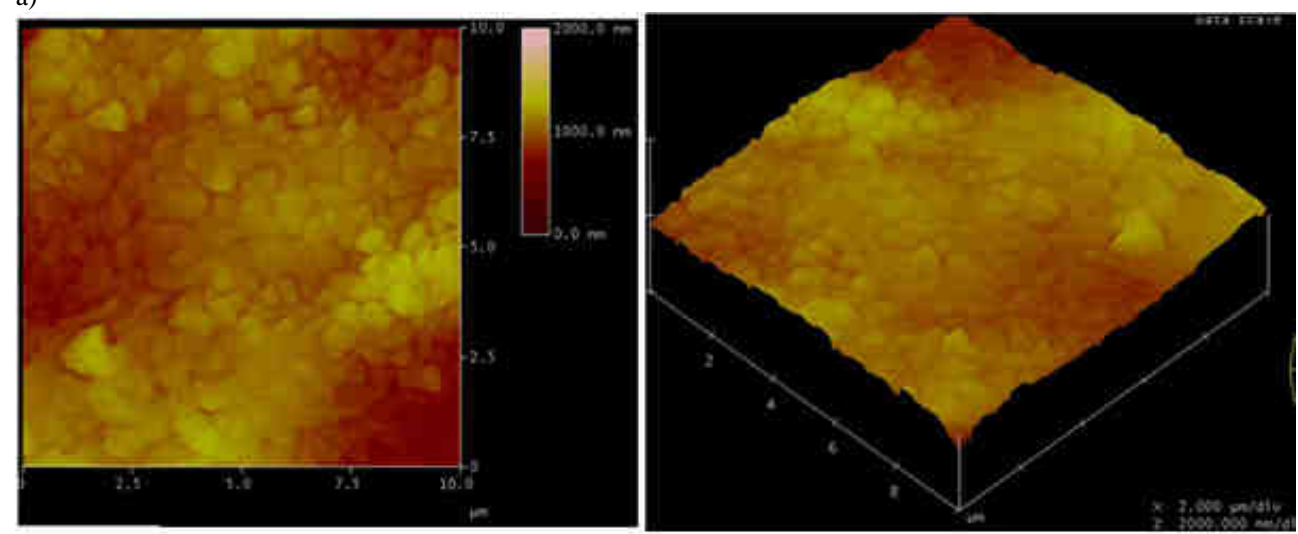

b)
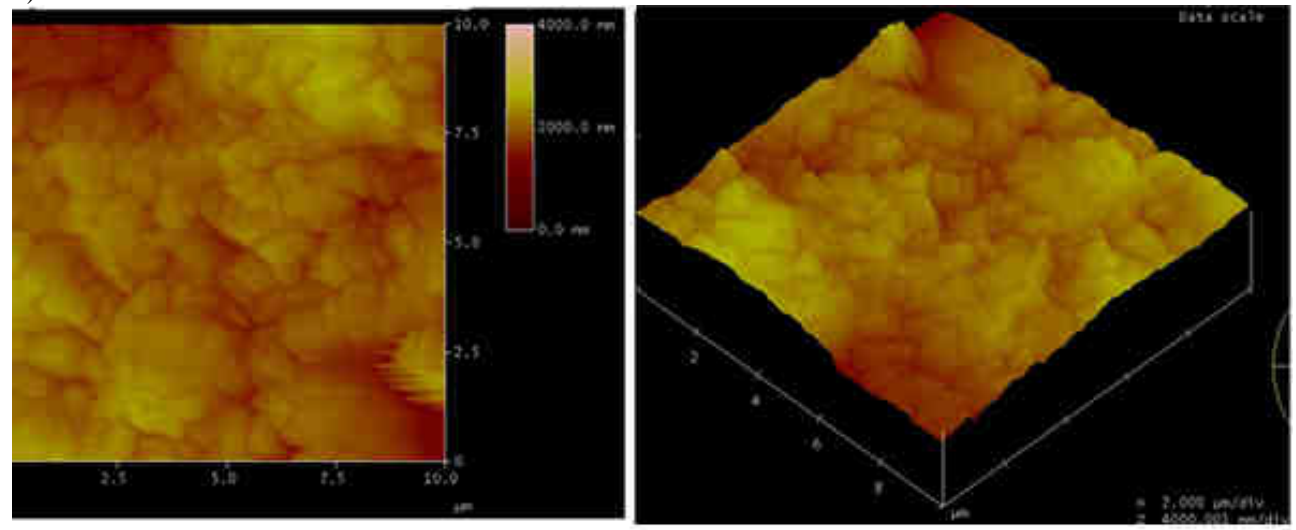

Fig. 4. AFM image of sorbent: a) before and b) after adsorption

a)

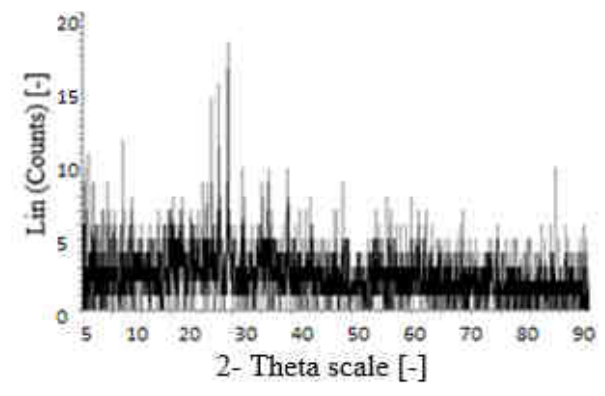

b)

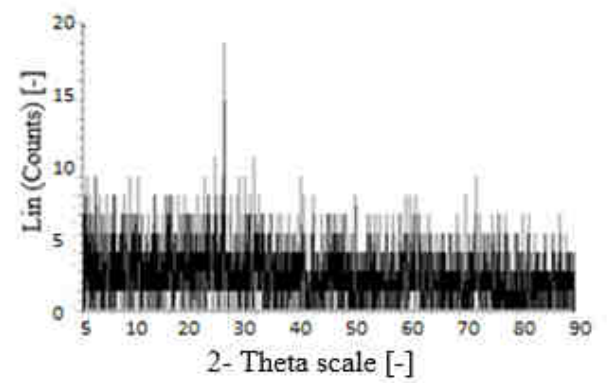

Fig. 5. XRD: a) before and b) after adsorption 
Surface and cross section images of the adsorbents were taken by using AFM to determine morphological properties such as surface porosity, roughness and texture [33]. Surface characterization involves micro-porosity, roughness and macro-pores size distribution measurements using atomic force microscopy before and after adsorption (Fig. 4). In Figure 5, XRD spectrum shows the sharp peaks of DWTP sludge. Similar peaks were present before and after adsorption, which indicates sorbent underwent no structural degradation during absorption.

\section{Batch adsorption experiments}

Batch equilibrium technique was used to remove $\mathrm{Ni}$ (II) ions from aqueous solution of DWTP sludge. Initial concentration of the solutions in the $\mathrm{pH}$ study was prepared using diluted $\mathrm{HCl}$ or $\mathrm{NaOH} .100 \mathrm{~cm}^{3}$ nickel solutions were put in $250 \mathrm{~cm}^{3}$ capped vials and then adsorbents were added. The tests were carried out with a temperature-controlled rotating shaker (Wise Shake, SHO-2D) within the specified period. Afterwards samples were subjected to centrifuge and free metal ions in the samples were analyzed with Merck NOVA60 UV spectrophotometer. Measurements were made by making appropriate dilutions (measurement range $0.02-5.00 \mathrm{mg} \mathrm{Ni} / \mathrm{dm}^{3}$ ). All $\mathrm{pH}$ readings were performed with Thermo Orion - STARA2145 brand $\mathrm{pH}$ meter.

The tests were performed at $\mathrm{pH}$ (3.0-7.0), with initial metal concentration $\left(5.0-50 \mathrm{mg} / \mathrm{dm}^{3}\right)$, contact time $(0-24$ hours $)$ and sorbent amount $\left(0.1-1.0 \mathrm{~g} / \mathrm{dm}^{3}\right)$, temperature $\left(20-50{ }^{\circ} \mathrm{C}\right)$, and shaking speed $(50-200 \mathrm{rpm})$. Isoterms were examined for initial concentration and the used sorbent amounts. Also, removal kinetics of $\mathrm{Ni}$ (II) ions was investigated for varying $\mathrm{pH}$ values (3-7).

Adsorption capacity $q_{e}$ and removal efficiency, $E[\%]$, were calculated using equations:

$$
\begin{gathered}
q_{e}=\frac{V \cdot\left(C_{o}-C_{e}\right)}{x} \\
E=\frac{\left(C_{o}-C_{e}\right)}{C_{o}} \cdot 100 \%
\end{gathered}
$$

where $q_{e}$ is the bound substance concentration $[\mathrm{mg} / \mathrm{g}] ; x$ is the adsorbent amount $[\mathrm{g}] ; V$ is the solution's volume $\left[\mathrm{cm}^{3}\right] ; C_{o}$ is the initial concentration $\left[\mathrm{mg} / \mathrm{dm}^{3}\right]$; and $C_{e}$ is the final concentration of the solution $\left[\mathrm{mg} / \mathrm{dm}^{3}\right]$.

\section{Results and discussion}

\section{Contact time}

Under specified conditions $\left(T=25{ }^{\circ} \mathrm{C}, C_{o}=25 \mathrm{mg} / \mathrm{dm}^{3}, x=0.3 \mathrm{~g}, \mathrm{pH}=5\right)$, nickel adsorption by DWTP sludge was investigated within 0-24 hours interval. Removal efficiency by percentage and $q_{e}$ are given in Figure 6. Adsorption capacity was increased with increasing contact time. Adsorption rate was initially high afterwards it slowed down and reached equilibrium after 20 hours. After equilibrium, adsorbed ion amount did not display a time-dependent change. This is mainly due to the presence of free active regions 
at the beginning of adsorption process which after a while will be occupied by adsorbate that slows down the adsorption process [34].

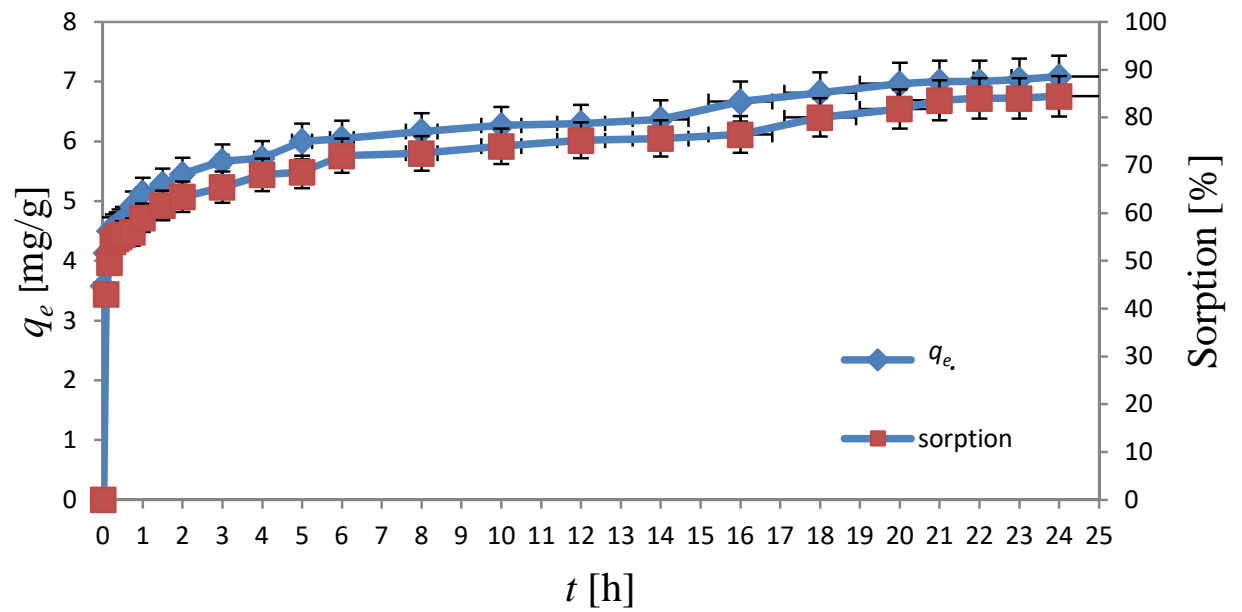

Fig. 6. Contact time

\section{Effect of solution pH on $\mathrm{Ni}(\mathrm{II})$ adsorption}

The tests were performed at $\mathrm{pH} 3-3.5-4-4.5-5-5.5-6-7$ (Fig. 7a). Low $\mathrm{pH}$ value at the beginning of the process triggers the increase in the number of cationic adsorbent regions and results in a decrease in the number of anionic adsorption regions. This leads to an increase in the hydrogen ion concentration of the solution, thus leading to an increased rate of electrostatic repulsion.

As the $\mathrm{pH}$ value increases, the number of anionic adsorption regions on DWTP sludge surface which in turn results in an increase in $\mathrm{OH}^{-}$ion concentration. Increasing electrostatic attraction force has a positive effect on the adsorption rate of nickel ions [35]. Evidently, lower $\mathrm{pH}$ facilitates the adsorption of ions by surface due to the presence of $\mathrm{H}^{+}$ ions, whereas, higher $\mathrm{pH}$ results in a more active surface for adsorption of cations as a result of deposition of $\mathrm{OH}^{-}$ions [36]. In this research $q_{e}$ was found as $6.12 \mathrm{mg} / \mathrm{g}$, and efficiency as $73.4 \%$ at $\mathrm{pH} \mathrm{3}$, whereas $q_{e}$ was found as $7.22 \mathrm{mg} / \mathrm{g}$ and efficiency was found as $86.6 \%$ at $\mathrm{pH} 7$. Increasing $\mathrm{pH}$ resulted in increased adsorption capacity and efficiency as also supported by other studies [37-39].

Following the adsorption process, total $\mathrm{Fe}\left(\mathrm{Fe}^{2+}+\mathrm{Fe}^{3+}\right)$ measurements were performed to detect the iron sludge's possible effects on water. An increase in the released amount of Fe was observed with increasing $\mathrm{pH}$. Total Fe amount was found as $0.4 \mathrm{mg} / \mathrm{dm}^{3}$ at $\mathrm{pH} \mathrm{3}$, whereas it was found as $0.9 \mathrm{mg} / \mathrm{dm}^{3}$ at $\mathrm{pH} 7$ (Fig. 7b). 
a)

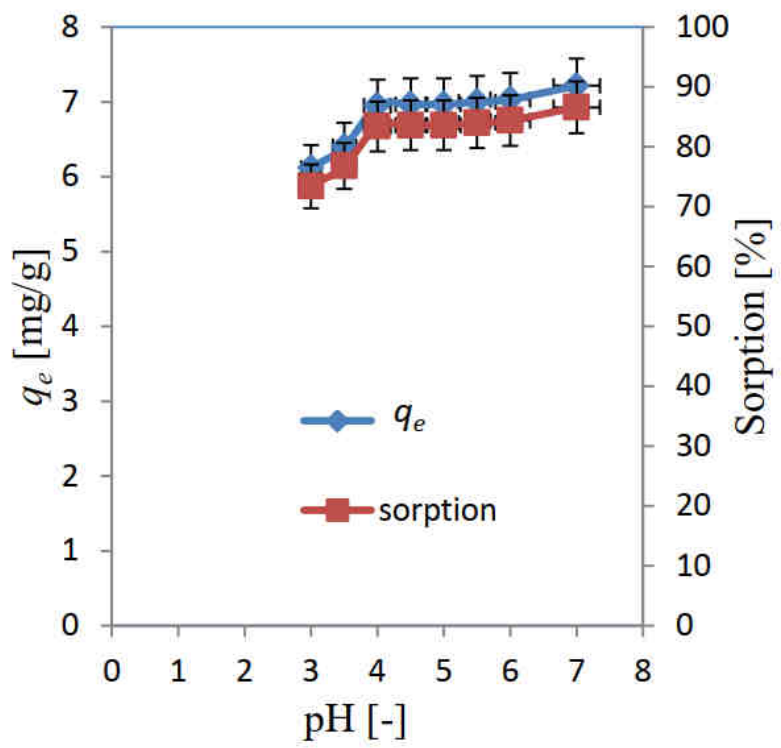

b)

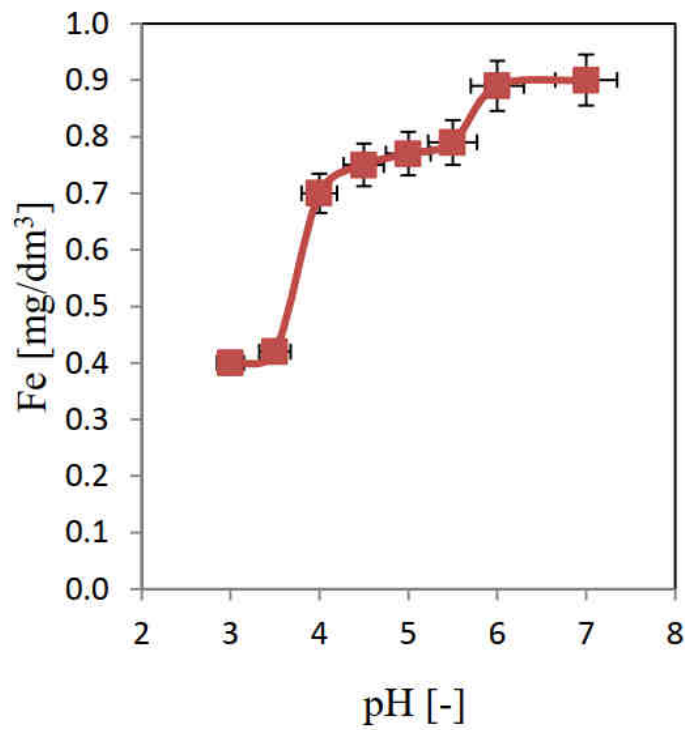

Fig. 7. Dependence: a) $q_{e}$, b) Fe amount on $\mathrm{pH}$

\section{Effect of adsorbent dose on $\mathrm{Ni}(\mathrm{II})$ adsorption}

Analyses were performed within $0.1-1 \mathrm{~g} / \mathrm{cm}^{3}$ interval to examine the change in adsorption efficiency depending on sorbent amount (Fig. 8a). The highest $q_{e}$ value $(16.20 \mathrm{mg} / \mathrm{g})$ was obtained with use of $0.1 \mathrm{~g}$ sorbent resulting with $64.8 \%$ efficiency. The highest efficiency was found as $89.4 \%$ for $1 \mathrm{~g}$ sorbent and $q_{e}$ was $2.24 \mathrm{mg} / \mathrm{g}$, which is 
consistent with previous studies [40, 41]. The reduction in adsorption capacity with increasing adsorbent dosage is mainly ascribed to the increase in unsaturated adsorption sites throughout the adsorption reaction. This also attributable to particle interactions such accumulation arising from high sorbent concentration. Such accumulations lead to lead to a decrease in total active surface regions of the adsorbent [34].

a)

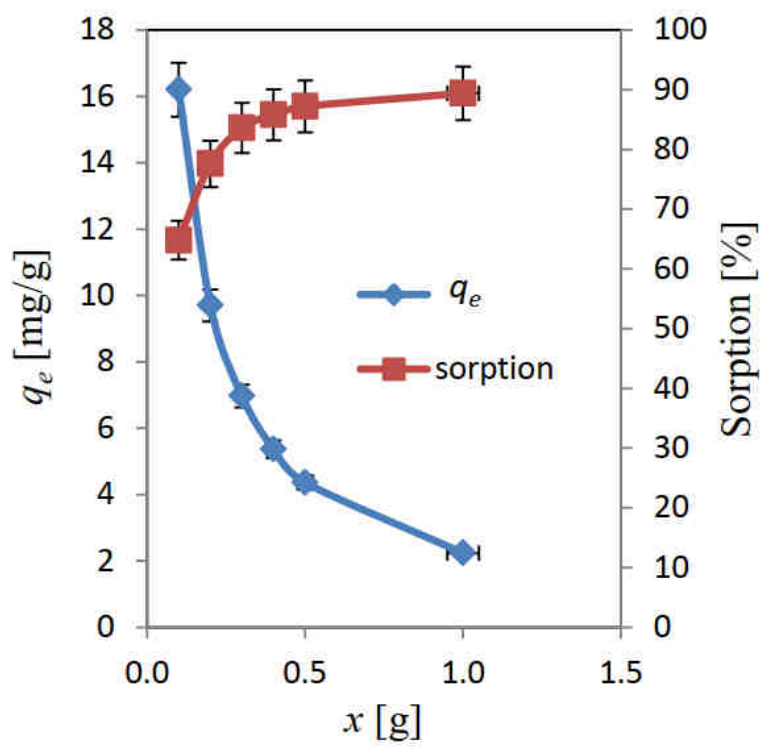

b)

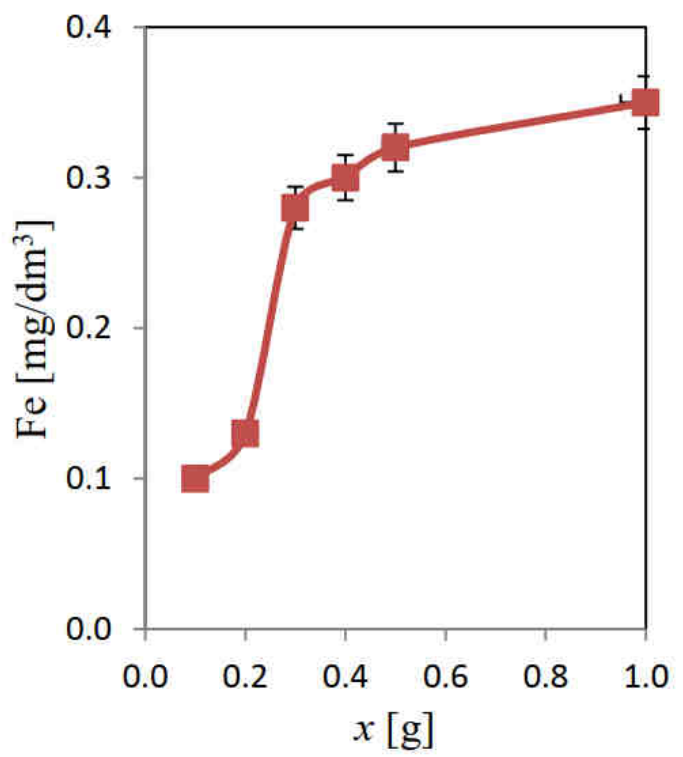

Fig. 8. Dependence: a) $q_{e}$, b) Fe amount on sorbent amount 
The increase in the amount of used sorbent and the change in $\mathrm{Fe}$ amount are shown in Figure $8 \mathrm{~b}$. An increase was observed in $\mathrm{Fe}$ amount depending on the sorbent amount. $0.1 \mathrm{mg} \mathrm{Fe} / \mathrm{dm}^{3}$ was measured when $0.1 \mathrm{~g}$ sorbent was used, and $0.35 \mathrm{mg} \mathrm{Fe} / \mathrm{dm}^{3}$ was measured when $1 \mathrm{~g}$ sorbent was used.

\section{Effect of initial concentration on $\mathrm{Ni}$ (II) adsorption}

a)

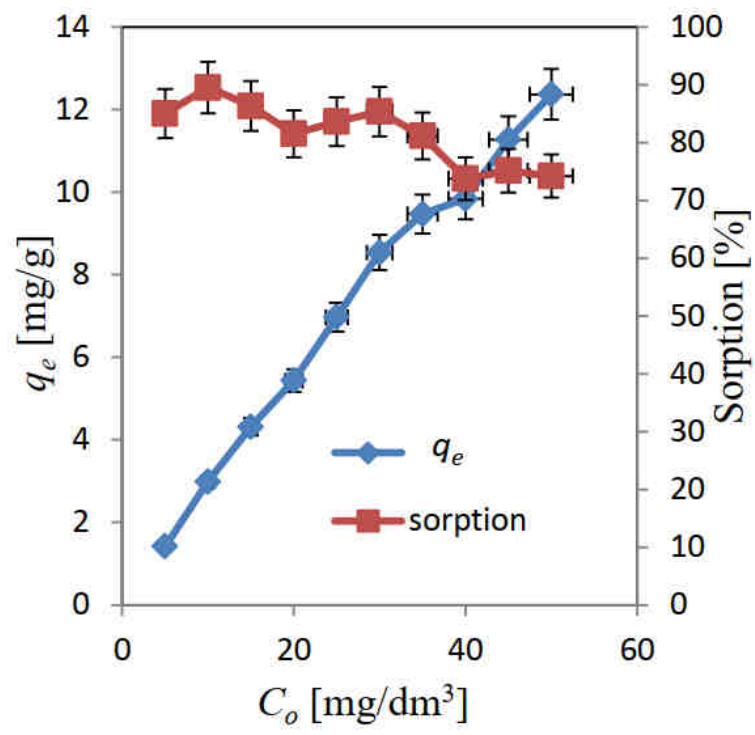

b)

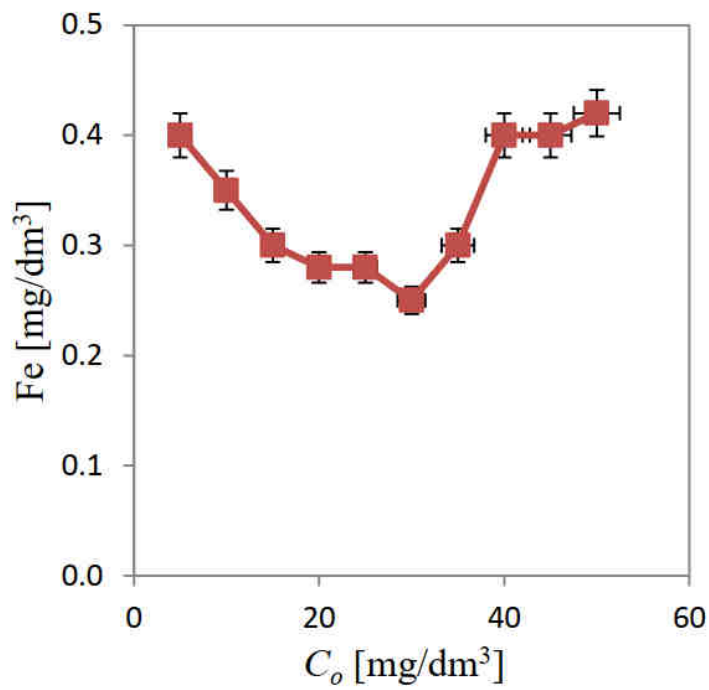

Fig. 9. Dependence: a) $q_{e}$, b) Fe amount on concentration of $\mathrm{Ni}(\mathrm{II})$ 
Initial concentration varied between $5-50 \mathrm{mg} / \mathrm{dm}^{3}$ during the study (Fig. 9). Higher initial concentrations increase the availability of nickel molecules, thus increasing the possibility to collide with sorbent surfaces [42]. Accordingly, efficiency increases increasing concentration [43, 44]. The highest $q_{e}$ value was measured as $12.37 \mathrm{mg} / \mathrm{g}$ for $50 \mathrm{mg} / \mathrm{dm}^{3} \mathrm{Ni}$ (II) concentration, whereas the lowest value was measured as $1.42 \mathrm{mg} / \mathrm{g}$ for $5 \mathrm{mg} / \mathrm{dm}^{3} \mathrm{Ni}$ (II) concentration. Initial concentration was observed to have no significant effect on the released amount of Fe ions (Fig. 9b).

a)

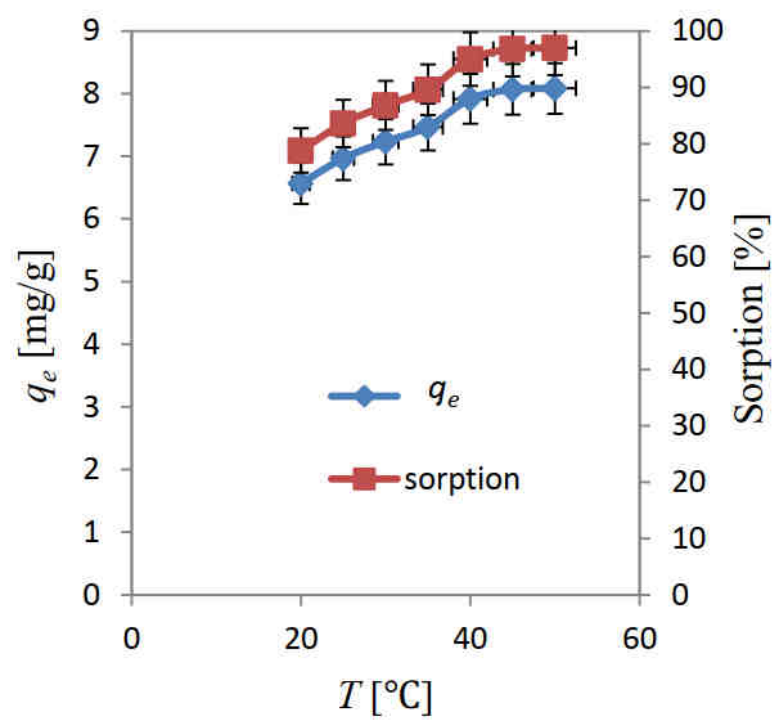

b)

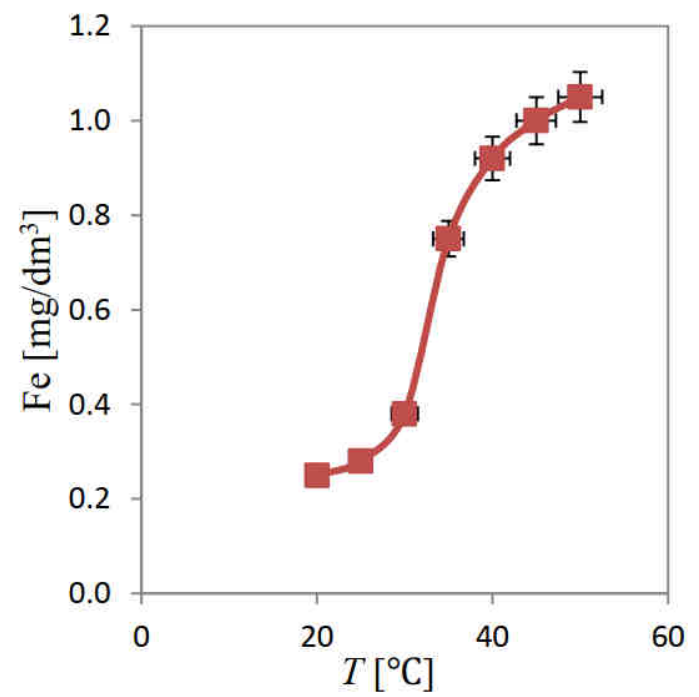

Fig. 10. Dependence: a) $q_{e}$, b) Fe amount on temperature of ambient 
a)

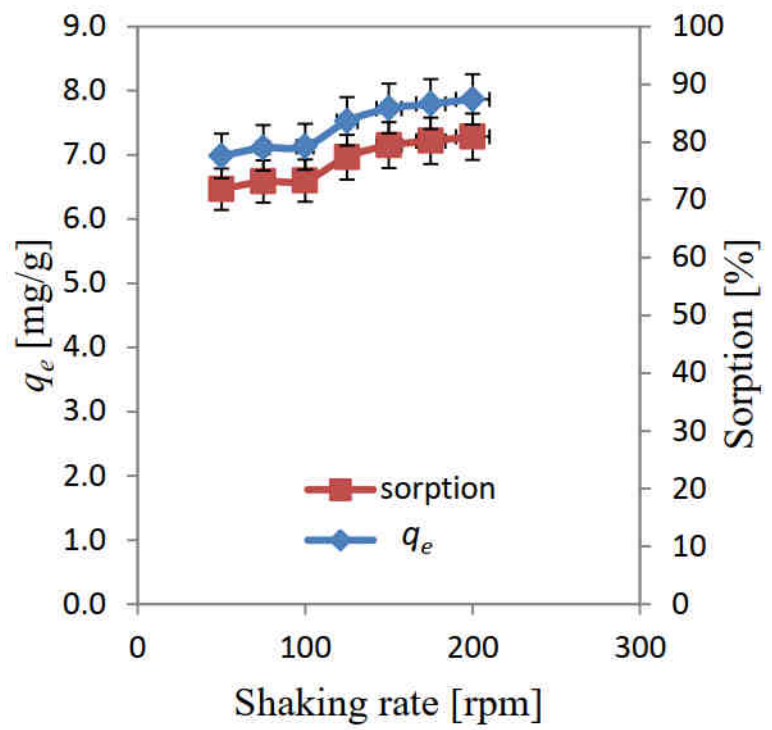

b)

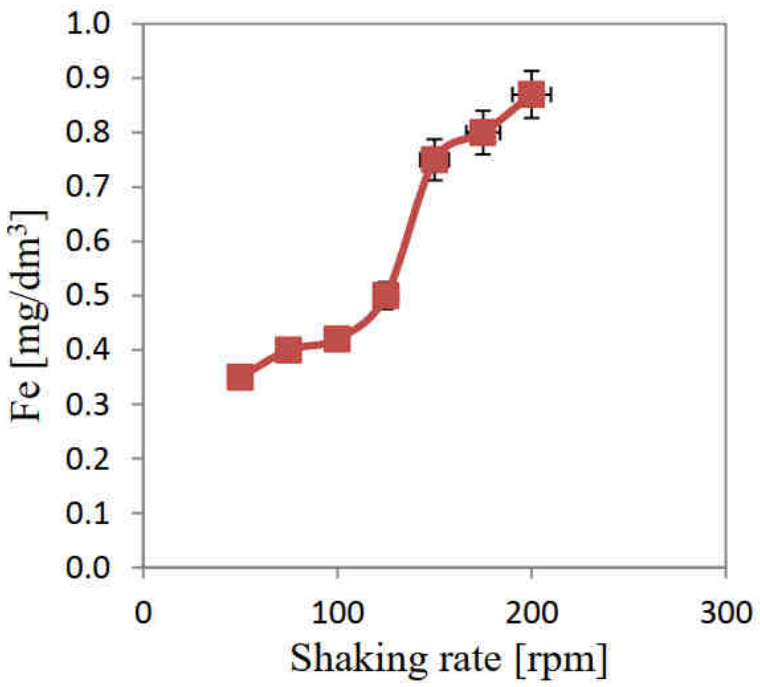

Fig. 11. Dependence: a) $q_{e}$, b) Fe amount on shaking rate

\section{Effect of temperature on $\mathrm{Ni}$ (II) adsorption}

The effect of temperature on adsorption was examined at $20-50{ }^{\circ} \mathrm{C}$ and the results are shown in Figure 10. As indicated in the Figure, adsorption capacity increased with increasing temperature. The process is considered to be exothermic. An increase in Fe amount is also observed with increasing temperature (Fig. 10b). The increase in sorbent 
amount at higher temperatures occurs as a result of increased impact frequency between sorbent and solute, which results in an increase sorption rate on sludge surface [45].

To adsorb a cation on sorbent surface; cation must be released by the surrounding water molecules. System requires additional energy for removal of these water molecules. If this energy exceeds the amount released after the binding of cation onto the sorbent, then overall sorption process is endothermic [46].

\section{Effect of shaking rate on $\mathrm{Ni}(\mathrm{II})$ adsorption}

Determination of the optimum shaking speed in wastewater treatment is crucial due to the energy consumption of this process and its effect on adsorption efficiency. The change in sorption efficiency related to the shaking speed is given in Figure 11a, and the change in $\mathrm{Fe}$ amount is given in Figure 11b. $q_{e}$ is $6.47 \mathrm{mg} / \mathrm{dm}^{3}$ and efficiency is $77.6 \%$ at $50 \mathrm{rpm}$, whereas, $q_{e}$ is $7.28 \mathrm{mg} / \mathrm{dm}^{3}$ and efficiency is $87.4 \%$ at $200 \mathrm{rpm}$. Fe amount is $0.35 \mathrm{mg} / \mathrm{dm}^{3}$ at $50 \mathrm{rpm}$ and 0.87 at $200 \mathrm{rpm}$. Such effect is attributable to the decrease in boundary layer thickness surrounding adsorbent particles as a result of increased shaking speed. External mass transfer rate of metals increases as a result of increasing heavy metal diffusion into the boundary layer between adsorbent particles and surrounding solution arising from increased shaking speed [47].

\section{Models}

\section{Kinetic modeling}

Kinetic tests were carried out at $\mathrm{pH}$ 3-4-5-6-7 for 0-20 hours. Pseudo-first order (Fig. 12a), pseudo-second order kinetic models (Fig. 12b), Weber and Morris model (Fig. 12c) and Elovich model (Fig. 12d) were applied on the obtained kinetic modeling results. The calculated kinetic constants are given in Table 1.

a)

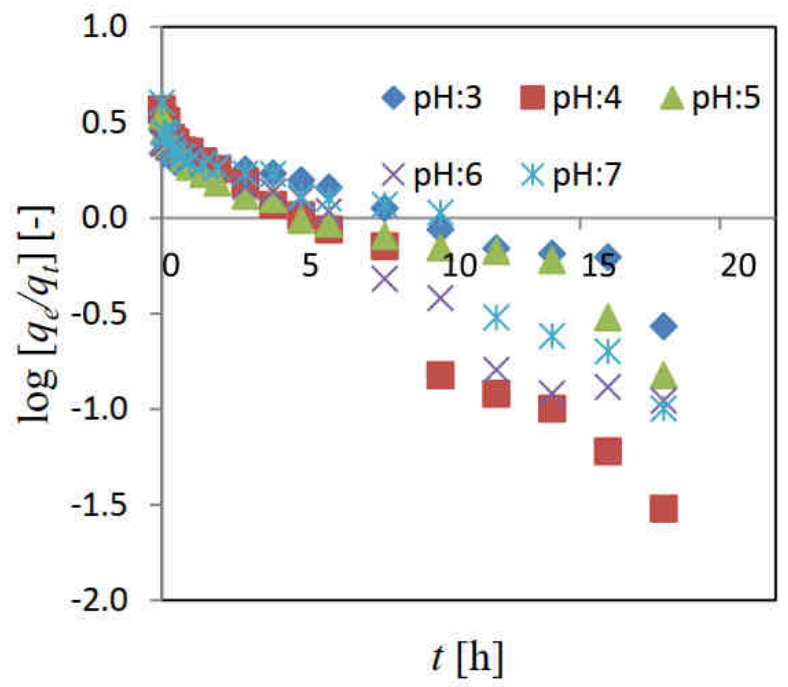


b)

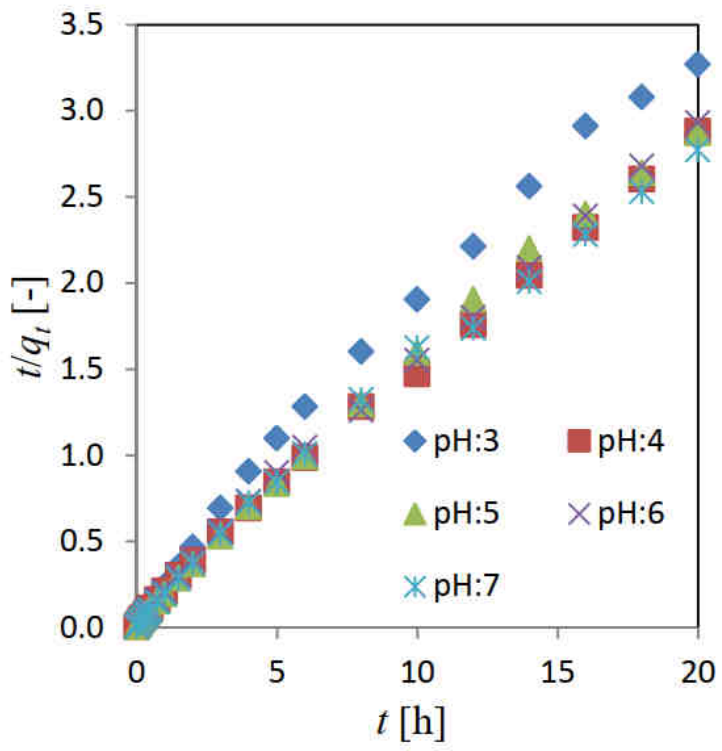

c)

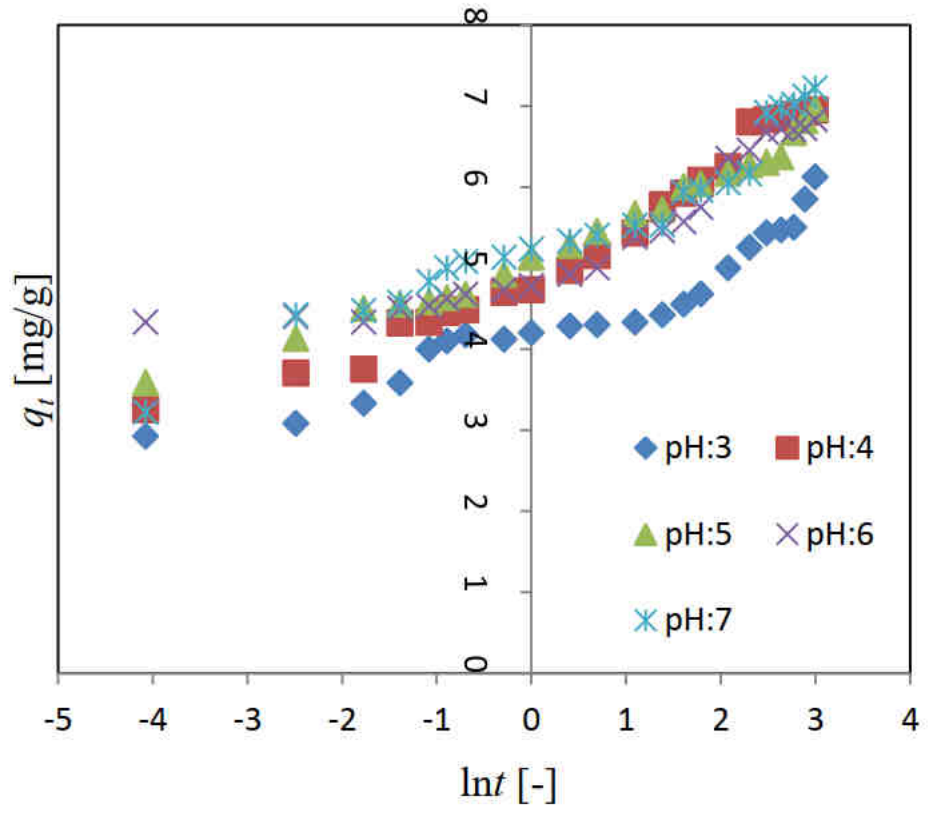


d)

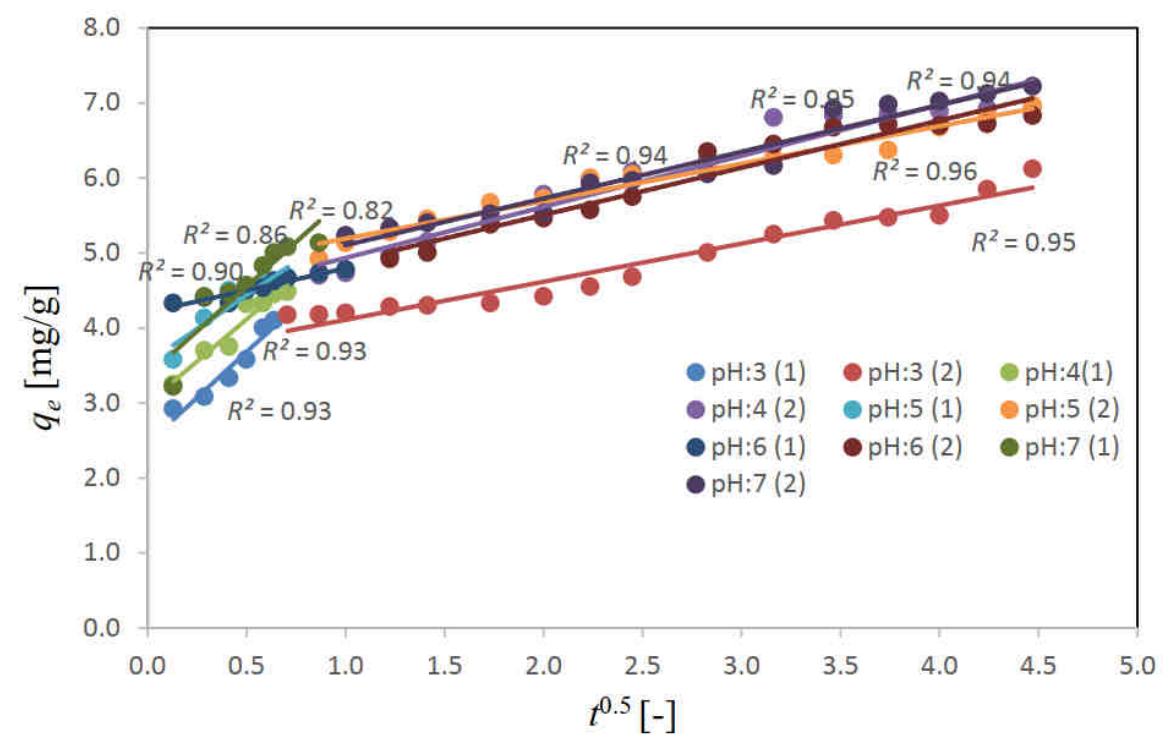

Fig. 12. Graphs of: a) pseudo-first order, b) pseudo-second order, c) Elovich and d) Weber-Morris kinetic models

Table 1

Kinetic constant for adsorption

\begin{tabular}{|c|c|c|c|c|c|c|c|c|c|c|c|c|c|}
\hline \multirow[t]{2}{*}{ pH } & \multirow{2}{*}{$\begin{array}{c}q_{\exp } \\
{[\mathrm{mg} / \mathrm{g}]}\end{array}$} & \multicolumn{3}{|c|}{ Pseudo-first order } & \multicolumn{3}{|c|}{$\begin{array}{c}\text { Pseudo-second } \\
\text { order }\end{array}$} & \multicolumn{6}{|c|}{ Weber-Morris } \\
\hline & & $\boldsymbol{k}_{f}$ & $q_{e}$ & $R^{2}$ & $\boldsymbol{k}_{S}$ & $q_{e}$ & $R^{2}$ & $\boldsymbol{k}_{i d}$ & $C$ & $R^{2}$ & $\boldsymbol{k}_{i d}$ & $C$ & $R^{2}$ \\
\hline 3 & 6.12 & 0.014 & 1.30 & 0.90 & 0.305 & 5.83 & 0.99 & 2.434 & 2.465 & 0.93 & 0.507 & 3.605 & 0.95 \\
\hline 4 & 6.95 & 0.008 & 1.00 & 0.97 & 0.315 & 7.02 & 0.99 & 0.243 & 2.994 & 0.93 & 0.680 & 4.255 & 0.94 \\
\hline 5 & 6.97 & 0.014 & 1.74 & 0.99 & 0.340 & 6.78 & 0.99 & 0.792 & 3.541 & 0.86 & 0.498 & 4.494 & 0.95 \\
\hline 6 & 7.03 & 0.015 & 3.15 & 0.96 & 0.283 & 6.99 & 0.99 & 0.585 & 4.21 & 0.90 & 0.629 & 4.250 & 0.94 \\
\hline \multirow[t]{3}{*}{7} & 7.22 & 0.025 & 3.02 & 0.97 & 0.284 & 7.14 & 0.99 & 2.739 & 4.362 & 0.82 & 0.621 & 4.483 & 0.95 \\
\hline & & \multicolumn{3}{|c|}{ Elovich } & & & & & & & & & \\
\hline & & $\beta$ & $\alpha$ & $R^{2}$ & & & & & & & & & \\
\hline 3 & 6.12 & 2.387 & 181 & 0.90 & & & & & & & & & \\
\hline 4 & 6.95 & 1.685 & 48.6 & 0.95 & & & & & & & & & \\
\hline 5 & 6.97 & 2.110 & 476 & 0.97 & & & & & & & & & \\
\hline 6 & 7.03 & 1.297 & 1071 & 0.84 & & & & & & & & & \\
\hline 7 & 7.22 & 1.967 & 290 & 0.93 & & & & & & & & & \\
\hline
\end{tabular}

\section{Pseudo-first order model}

Lagergren [48] reported that the adsorption of pollutants on the adsorbent complies to a pseudo-first order model:

$$
\log \left(q_{e}-q_{t}\right)=\log q_{e}-\frac{k_{f}}{2.303} t
$$


where $q_{e}$ and $q_{t}$ are the sorption capacity [mg/g] of adsorbent at equilibrium, and time $t$ [min], respectively, and $k_{f}$ is the pseudo-first-order sorption rate constant $\left[\mathrm{s}^{-1}\right]$.

\section{Pseudo-second order model}

Ho and McKay [49] introduced the pseudo-second order kinetic model for sorption as given below:

$$
\frac{t}{q_{t}}=\frac{1}{k_{s} q_{e}^{2}}+\frac{1}{q_{e}} t
$$

where $k_{S}$ is the pseudo-second order sorption rate constant $[\mathrm{g} /(\mathrm{mg} \mathrm{s})]$; at $t=0, k_{s} q_{e}{ }^{2}$ is adsorption rate which is thus termed as initial sorption rate, $h[\mathrm{mg} /(\mathrm{g} \mathrm{s})]$.

As indicated in Table 1 , the highest $R^{2}$ values $(0.99)$ are obtained with pseudo-second order model. Also, when compared with pseudo-first order model, the theoretical $q_{e}$ models yielded by this model were found to be closer to experimental $q_{e}$ values. Consequently, adsorption process was found to be in compliance with pseudo-second order kinetic model. Similar kinetic behaviours were also reported in previous studies [33, 34, 50].

\section{Weber and Morris model (Intraparticle diffusion)}

Intraparticle diffusion model was tested to determine the diffusion mechanisms and rate limiting steps in adsorption process. The theory of the model was introduced by Weber and Morris (Eq. (5)) [51]:

$$
q=k_{i d} t^{0.5}+C
$$

In this model, $k_{i d}\left[\mathrm{mg} \mathrm{g}^{-1} \min ^{1 / 2}\right]$ denotes the intraparticle diffusion rate constant which is affected by temperature and particle diameter, while $C$ is the intercept value that gives an estimated thickness of the boundary layer, i.e. the larger is the intercept, the greater is the boundary effect.

As shown in Figure 12d, nickel adsorption does not intercept with origin for all $\mathrm{pH}$ values and it occurs in two steps. The rate constants for the two resulting steps were $k_{i d 1}>k_{i d 2}$ for $\mathrm{pH} 3-5-7$ and $k_{i d 2}>k_{i d 1}$ for $\mathrm{pH} 4-6$ and $C$ values for each step increase with increasing $\mathrm{pH}$ value. This is indicative of the increase in boundary layer thickness with increasing $\mathrm{pH}$, and the consequent decrease in diffusion rate [52].

\section{Elovich model}

Elovich's equation has been widely applied to define adsorption of gases on solid materials. This equation is also used to define heavy metal adsorption in aqueous solutions. The model defines the kinetics of chemical adsorption process using the following equation [53]:

$$
q_{t}=\frac{1}{\beta_{e}} \ln \left(\alpha \beta_{e}\right)+\frac{1}{\beta_{e}} \ln t
$$


where $\alpha$ is the initial rate $[\mathrm{mg} / \mathrm{g} \mathrm{min}]$ as $\left(d_{q t} / d_{t}\right)$ converges to $\beta_{e}$ when $q_{t}$ converges to zero, and the parameter $\beta_{e}$ relates to extent of activation energy and surface coverage for chemisorptions $[\mathrm{g} / \mathrm{mg}]$.

High correlation coefficients were obtained for all $\mathrm{pH}$ values in Elovich kinetic model (Table 1). Similar results were also reported in previous studies [54, 55]. This is indicative of the higher significance of limited diffusion rate in Ni(II) adsorption with DWTP sludge. According to the results, the rate can be increased but increasing the adsorption temperature. This tendency regarding $\beta_{e}$ is consistent with those in conventionally activated chemical adsorption systems that indicates that $\beta_{e}$ relates to the regions available for absorption.

Reportedly, Ni(II) adsorption on DWTP sludge may involve valance forces through electron share or exchange between adsorbent and adsorbate [56]. This may correspond to exchangeable $\mathrm{H}+$ ions and $\mathrm{OH}$ groups available in DWTP sludge. Accordingly, ion exchange mechanism plays a major role in the adsorption process. The literature reports countless studies on heavy metal removal from waters and effluents, including chemical precipitation, such as ion exchange and adsorption. Studies of many authors indicate that the ion exchange process is one of the main mechanisms of sorption of heavy metals [57-61].

\section{Equilibrium modeling}

Adsorption isotherm gives an estimation of how adsorption molecules are distributed among liquid and solid phases when adsorption process reaches equilibrium. The data obtained from the tests performed with different $\mathrm{Ni}$ (II) concentrations $\left(C_{o}\right)$ and sorbent dosages $(x)$ were used in Langmuir, Freundlich, Temkin and D-R (Dubinin-Radushkevich) models. Isotherm parameters for adsorption process are given in Table 2.

Table 2

Adsorption isotherm parameters

\begin{tabular}{|c|c|c|c|}
\hline \multirow{2}{*}{ Model } & \multicolumn{3}{|c|}{ Isotherm parameters } \\
\cline { 2 - 4 } & & $\boldsymbol{C}_{\boldsymbol{o}}\left[\mathbf{m g} / \mathbf{d m}^{3}\right]$ & $\boldsymbol{x}[\mathbf{g}]$ \\
\hline \multirow{3}{*}{ Langmuir } & $R^{2}$ & 0.90 & 0.92 \\
& $K_{a}\left[\mathrm{dm}^{3} / \mathrm{mg}\right]$ & 6.90 & 2.62 \\
& $Q_{\max }[\mathrm{mg} / \mathrm{g}]$ & 2.63 & 0.22 \\
& $R_{L}$ & 0.005 & 0.015 \\
\hline \multirow{3}{*}{ Freundlich } & $R^{2}$ & 0.92 & 0.95 \\
& $K_{F}\left[\mathrm{dm}^{3} / \mathrm{g}\right]$ & 2.41 & 9.95 \\
& $n$ & 1.48 & 3.72 \\
\hline \multirow{3}{*}{ Temkin } & $R^{2}$ & 0.86 & 0.93 \\
& $A\left[\mathrm{dm}^{3} / \mathrm{g}\right]$ & 1.07 & 0.05 \\
& $B$ & 3.81 & -1.33 \\
\hline \multirow{3}{*}{ D-R } & $R^{2}$ & 0.89 & 0.63 \\
& $\beta\left[\mathrm{mol}^{2} / \mathrm{J}^{2}\right]$ & -0.40 & 1.61 \\
& $q_{\max }[\mathrm{mg} / \mathrm{g}]$ & 9.19 & 0.99 \\
& $E_{a d s}[\mathrm{~kJ} / \mathrm{mol}]$ & 1.107 & 0.39 \\
\hline
\end{tabular}

\section{Langmuir isotherm}

Langmuir model assumes that adsorbates are present on specific homogeneous regions on adsorbents and this model is successfully used in various monolayer adsorption processes [62]. The nonlinear form of Langmuir isotherm model is defined with the following equation [63]: 


$$
q_{e}=\frac{Q_{\max } \cdot K_{a} \cdot C_{e}}{1+K_{a} \cdot C_{e}}
$$

where $Q_{\max }$ denotes the maximum adsorbate uptake at equilibrium state, $C_{e}$ is the adsorbate concentration at equilibrium and $K_{a}$ is the coefficient for the affinity between the adsorbate and adsorbant.

The main characteristic of Langmuir isotherm is its provability with the dimensionless equilibrium constant termed $R_{L}$ :

$$
R_{L}=\frac{1}{1+K_{a} \cdot C_{o}}
$$

where $C_{o}$ is the initial $\mathrm{Ni}(\mathrm{II})$ concentration. $R_{L}$ values indicate whether the isotherm is irreversible $\left(R_{L}=0\right)$, favorable $\left(0<R_{L}<1\right)$, linear $\left(R_{L}=1\right)$ or unfavorable $\left(R_{L}>1\right)$ [64]. In this study, $R_{L}$ values were found between zero and one, which indicates that, Langmuir isotherm is suitable for use in $\mathrm{Ni}(\mathrm{II})$ adsorption with DWTP sludge.

\section{Frendlich isotherm}

Freundlich isotherm applies for both monolayer (chemical adsorption) and multilayer adsorption (physical adsorption) and it is based on the assumption that adsorbent adsorbate is adsorbed on the heterogeneous surface of the adsorbent [65]. Frendlich equation is given:

$$
q_{e}=k \cdot C_{e^{\frac{1}{n}}}
$$

where $k$ is the adsorption capacity and " $n$ " is the Freundlich constant related to the intensity of adsorption. There is a positive correlation between the magnitude of " $n$ " and adsorption intensity. In general " $n$ " values in 2-10 interval indicate good adsorption, values between 1-2 indicate limited adsorption and values lower than 1 indicate weak adsorption characteristic [66]. In this study " $n$ " was found as 1.48 for $C_{o}$ and as 3.723 for $x$. Also the highest $R^{2}$ values were found at Freundlich isotherm. It is reported in various other researches that Freundlich is the best isotherm for adsorption process [67, 68].

\section{Dubinin-Radushkevich (D-R) isotherm}

The D-R isotherm was developed to explain the effect of the porous structure of a sorbent on adsorption [69]. The model can also be applied to define whether a $\mathrm{Ni}$ (II) adsorption process is physical or chemical in nature. The linearised D-R isotherm is defined as below:

$$
\ln q_{e}=\ln q_{\max }-\beta \cdot \varepsilon^{2}
$$

where $\beta$ is the constant related with adsorption average free energy per 1 mole of adsorbed material $\left[\mathrm{mol}^{2} / \mathrm{J}^{2}\right], q_{e}$ is the adsorbed amount at equilibrium $[\mathrm{mol} / \mathrm{g}], q_{\max }$ is the theoretical 
saturation capacity $[\mathrm{mol} / \mathrm{g}]$ and $\varepsilon$ is Polanyi potential $[\mathrm{kJ} / \mathrm{mol}]$ calculated with the following equation:

$$
\varepsilon=\mathrm{R} \cdot T \cdot \ln \left(1+\frac{1}{C_{e}}\right)
$$

In the equation; $\mathrm{R}$ denotes the universal gas constant $\mathrm{R}=8.314 \mathrm{~J} /(\mathrm{mol} \cdot \mathrm{K})$ and $T$ is the absolute temperature $[K]$. The graph of $\ln q_{e}$ values versus $\varepsilon^{2}$ values yields a line with slope $-\beta$ and intercept $\ln q_{\max } . \beta$ gives an estimation of the average free energy of adsorption per one molecule of adsorbed material. The relationship between these values is defined in equation [70]:

$$
E_{a d s}=\frac{1}{\sqrt{2 \beta}}
$$

This parameter gives an idea as to which of the chemical ion or physical adsorption mechanisms is effective. Average adsorption energy, $E_{a d s}$, values between $8-16 \mathrm{~kJ} / \mathrm{mol}$ indicate chemical ion exchange, and values lower than $8 \mathrm{~kJ} / \mathrm{mol}$ indicate physical adsorption mechanism [71]. In this study, sorption mechanism can be associated with physical interactions as $E$ values are found to be lower than $8 \mathrm{~kJ} / \mathrm{mol}$.

\section{Temkin isotherm}

Temkin isotherm assumes that, the heat from adsorption of all molecules in the layer displays a linear decrease with the coverage of molecules, and the adsorption process is uniformly distributed due to the adsorbate - adsorbate repulsions. Temkin isotherm is defined by equation [72]:

$$
q_{e}=B_{T} \ln A_{T}+B_{T} \ln C_{e}
$$

where $B_{T}$ relates to the adsorption heat and $A_{T}$ is the equilibrium binding constant. $B_{T}$ and $A_{T}$ can be estimated via a plot of $q_{e}$ versus $\ln C_{e}$. In this research, high $R^{2}$ values were obtained particularly for varying $C_{o}$ value $(0.93)$.

\section{Thermodynamic parameters}

Thermodynamic parameters for adsorption such as Gibbs free energy change $\left(\Delta G^{0},[\mathrm{~J} / \mathrm{mol}]\right)$, enthalpy change $\left(\Delta H^{0},[\mathrm{~J} / \mathrm{mol}]\right)$ and entropy change $\left(\Delta S^{0},[\mathrm{~J} / \mathrm{mol} \mathrm{K}]\right)$ can be estimated using the following equations [73]:

$$
\begin{aligned}
& \Delta G^{0}=\Delta H^{0}-T \Delta S^{0} \\
& \ln K_{c}=\frac{\Delta G^{0}}{\mathrm{R}}+\frac{\Delta H^{0}}{\mathrm{R} T}
\end{aligned}
$$


where $\mathrm{R}$ is the universal gas constant, $K_{c}$ is adsorption equilibrium constant and $T$ is absolute temperature $[\mathrm{K}]$. The Gibbs free energy value of an adsorption process at a given temperature can be calculated with $K_{c}$ via the equation: $\Delta G^{0}=-R T \ln K_{c}$.

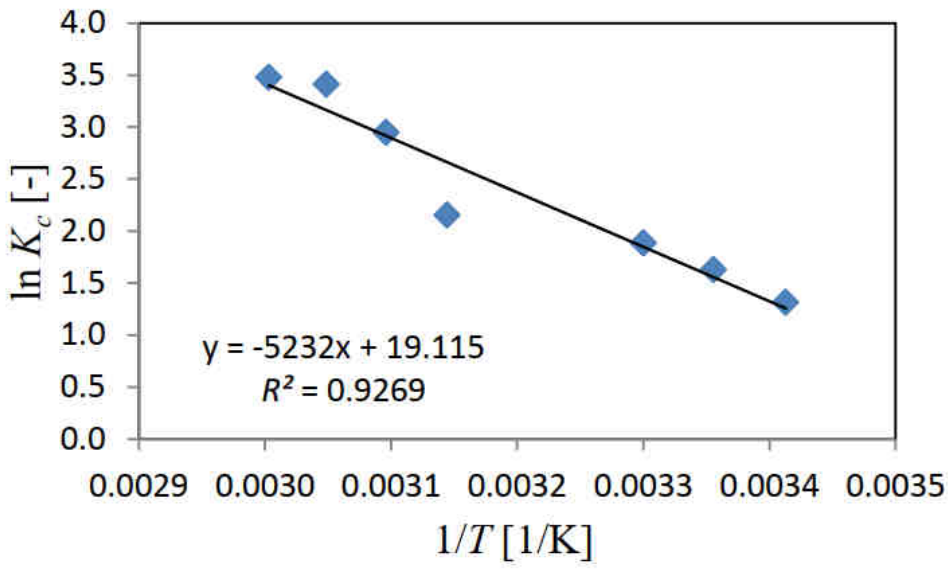

Fig. 13. Van t'Hoff graph

$\ln K_{c}-1 / T$ (Van t'Hoff) graph obtained for varying temperatures is given in Figure 13 and the thermodynamic parameters are given in Table 3 . According to the results, $\Delta G^{0}$ value is negative at varying temperature intervals. Negative Gibbs free energy values for all temperatures verify the spontaneousness and applicability of biosorption process [74]. Also the decrease in the negative value of $\Delta G^{0}$ with increasing temperature indicates that, adsorption process is facilitated at higher temperatures. The result is consistent with the temperature effect on the dynamics.

Table 3

Thermodynamic parameters

\begin{tabular}{|c|c|c|c|c|}
\hline $\boldsymbol{T}[\mathbf{K}]$ & $\begin{array}{c}\boldsymbol{b} \\
{\left[\mathbf{d m}^{\mathbf{3}} / \mathbf{g}\right]}\end{array}$ & $\begin{array}{c}\Delta \boldsymbol{G}^{\mathbf{0}} \\
{[\mathbf{k J} /(\mathbf{K} \cdot \mathbf{m o l})]}\end{array}$ & $\begin{array}{c}\Delta \boldsymbol{H}^{\mathbf{0}} \\
{[\mathbf{k J} /(\mathbf{K} \cdot \mathbf{m o l})]}\end{array}$ & $\begin{array}{c}\Delta \boldsymbol{S}^{\mathbf{0}} \\
{[\mathbf{k J} /(\mathbf{K} \cdot \mathbf{m o l})]}\end{array}$ \\
\hline 293 & 1.24 & -3.20 & & \\
\hline 298 & 1.70 & -4.04 & & \\
\hline 303 & 2.19 & -4.74 & -43.49 & \\
\hline 308 & 2.87 & -5.51 & & \\
\hline 313 & 6.33 & -7.66 & & \\
\hline 318 & 10.08 & -9.01 & & \\
\hline 323 & 10.78 & -9.33 & & \\
\hline
\end{tabular}

Negative $\Delta H^{0}$ values are indicative of an exothermic adsorption process, and positive values indicate an endothermic process. Negative $\Delta G^{0}$ and $\Delta H^{0}$ values were also reported in other studies $[41,75]$.

The positive value of $\Delta S^{0}$ indicates some changes in the adsorbent and adsorbate structures, and increased adsorption rates also lead to increased disorder or randomness of the entire system. The obtained thermodynamic parameters show that, DWTP sludge can be used as an efficient adsorbent for $\mathrm{Ni}$ (II) removal from aqueous solution. 
The studies in the literature on adsorption related with $\mathrm{Ni}$ (II) ions were examined and compared with the values obtained in the present study (Table 4).

Comparison of adsorption capacity of the present system with other studies

\begin{tabular}{|c|c|c|}
\hline Adsorbent & Adsorption capacity [mg/g] & Reference \\
\hline Bamboo powder & 32.57 & {$[76]$} \\
\hline Coconut shells & 83.16 & {$[77]$} \\
\hline Rice hull & 5.02 & {$[78]$} \\
\hline Modified mangrove barks & 4.78 & {$[79]$} \\
\hline Sargassum ilicifolium & $1.85-1.425$ & {$[80]$} \\
\hline Zeolite & 1.98 & {$[81]$} \\
\hline Bentonite & 19.92 & {$[55]$} \\
\hline Montmorillonite & 28.4 & {$[82]$} \\
\hline Montmorillonite & 21.1 & {$[83]$} \\
\hline Vermiculite & 0.229 & {$[84]$} \\
\hline Coal fly ash prepared zeolite & 8.96 & {$[85]$} \\
\hline DWTP sludge & 6.97 & This study \\
\hline
\end{tabular}

\section{Conclusions}

The adsorption by DWTP sludge proved to be effective in removal of nickel ions from water. Comprehensive researches have been performed to evaluate the effect of different parameters on adsorption. Adsorbate amount, solution's $\mathrm{pH}$, metal concentration and temperature are among these parameters which are reported to be effective on adsorption. In various studies, pseudo first order and pseudo second order kinetics have been used to model adsorption kinetics. In these studies, pseudo second order kinetic model was found to yield more accurate results as in the case of this research. The rate constants in the intra-particle diffusion model varied as $k_{i d 1}>k_{i d 2}$, and $\mathrm{C}$ values at each step increased with increasing $\mathrm{pH}$. In terms of equilibrium, Langmuir isotherm proved to be suitable for $\mathrm{Ni}(\mathrm{II})$ adsorption with DWTP sludge, whereas the results from Freundlich model were also consistent with experimental data in several situations. Isotherms other than Temkin and DR models were also successfully applied in other researches to estimate the adsorption equilibrium. In this research, the $\mathrm{E}$ values lower than $8 \mathrm{~kJ} / \mathrm{mol}$ in $\mathrm{DR}$ model led to the assumption that sorption mechanism is based on physical interactions. Also, the conducted thermodynamic study yielded a negative $\Delta G^{0}$ value, which verifies the spontaneousness and applicability of the biosorption process. The obtained thermodynamic parameters showed that DWTP sludge can be used as an efficient adsorbent in removal of $\mathrm{Ni}$ (II).

\section{Acknowledgements}

This work is supported by the Scientific Research Project Fund of Cumhuriyet University under the Project number M-633. I sincerely thank CÜBAP Chairmanship for their endorsement.

\section{References}

[1] Wan Ngah WS, Hanafiah MAKM. Removal of heavy metal ions from wastewater by chemically modified plant wastes as adsorbents. A review. Bioresour Technol. 2008;99:3935-3948. DOI: 10.1016/j.biortech.2007.06.011.

[2] Zadaviciüte $\mathrm{S}$, Baltakys $\mathrm{K}$, Eısınas A. Adsorption kinetic parameters of $\mathrm{Fe}^{3+}$ and $\mathrm{Ni}^{2+}$ ions by gyrolite. Materıals Scı. (Medžıagotyra). 2015;21(1):117-122. DOI: 10.5755/j01.ms.21.1.5735. 
[3] Kamiński K, Kamiński W, Mizerski T. Application of artificial neural networks to the technical condition assessment of water supply systems. Ecol Chem Eng S. 2017;24(1):31-40. DOI: 10.1515/eces-2017-0003.

[4] Blakemore R, Chandler R, Surrey T, Ogilvie D, Walmsley N. Management of Water Treatment Plant Residuals in New Zealand, first ed. Auckland: Water Supply Managers' Group, New Zealand Water and Wastes Association; 1998; 56.

[5] Zhao YQ, Babatunde AO, Hu YS, Kumar JLG, Zhao XH. Pilot field-scale demonstration of a novel alum sludge-based constructed wetland system for enhanced wastewater treatment. Process Biochem. 2011;46(1):278-283. DOI: 10.1016/j.procbio.2010.08.023.

[6] Vaebi F, Batebi F. Recovery of iron coagulants from tehran water-treatment-plant sludge for reusing in textile wastewater treatment. Iran J Public Health. 2001;30(3-4):135-138.

[7] Miroslav K. Opportunities for water treatment sludge reuse, J Geosci Eng. 2008;54(1):11-22.

[8] Pereira FR, Nunes AF, Segadaes AM, Labrincha JA. Refractory mortars made of different wastes and natural sub-products. Key Eng Mater. 2004;264-268:1743-1747. DOI: 10.4028/www.scientific.net/KEM.264-268.1743.

[9] Siswoyo E, Mihara Y, Tanaka S. Determination of key components and adsorption capacity of a low cost adsorbent based on sludge of drinking water treatment plant to adsorb cadmium ion in water. Appl Clay Sci. 2014;97-98:146-152. DOI: 10.1016/j.clay.2014.05.024.

[10] Cherifi M, Hazourli S, Pontvianne S, Leclerc JP, Lapicque F. Electrokinetic removal of aluminum from water potabilization treatment sludge. Desalination. 2011;281(17):263-270. DOI: 10.1016/j.desal.2011.07.071.

[11] Hong GX, Hao CG, Chii S. Re-use of water treatment works sludge to enhance particulate pollutant removal from sewage. Water Res. 2005;39(15):433-3440. DOI: 10.1016/j.watres.2004.07.033.

[12] Yang L, Wei J, Zhang YM, Wang JL, Wang DT. Reuse of acid coagulant-recovered drinking waterworks sludge residual to remove phosphorus from wastewater. Appl Surf Sci. 2014;305:337-346. DOI: 10.1016/j.apsusc.2014.03.081.

[13] Krishna KCB, Aryal A, Jansen T. Comparative study of ground water treatment plants sludges to remove phosphorous from wastewater. J Environ Manage. 2016;180:17-23. DOI: 10.1016/j.jenvman.2016.05.006.

[14] Hasan H, Abdullah SRS, Kofli NT, Kamarudin SK. Isotherm equilibria of $\mathrm{Mn}^{2+}$ biosorption in drinking water treatment by locally isolated Bacillus species and sewage activated sludge. J Environ Manage. 2012;30:34-43. DOI: 10.1016/j.jenvman.2012.06.027.

[15] Vinitnantharat S, Kositchaiyong S, Chiarakorn S. Removal of fluoride in aqueous solution by adsorption on acid activated water treatment sludge. Appl Surf Sci. 2010;256(17-15):5458-5462. DOI: 10.1016/j.apsusc.2009.12.140.

[16] Gibbons MK, Gagnon GA. Adsorption of arsenic from a Nova Scotia ground-water onto water treatment residual solids. Water Res. 2010;44:5740-5749. DOI: 10.1016/j.watres.2010.06.050.

[17] Kim YS, Kim DH, Yang JS, Baek K. Adsorption characteristics of As(III) and As(V) on alum sludge from water purification facilities. Sep Sci Technol. 2012;47:2211-2217. DOI: 10.1080/01496395.2012.700676.

[18] Irawan C, Liu JC, Wu CC. Removal of boron using aluminum-based water treatment residuals (Al-WTRs). Desalination. 2011;276:322-327. DOI: 10.1016/j.desal.2011.03.070.

[19] Yang L, Wei J, Liu Z, Wang J, Wang D. Material prepared from drinking waterworks sludge as adsorbent for ammonium removal from wastewater. Appl Surf Sci. 2015;330:228-236. DOI: 10.1016/j.apsusc.2015.01.017.

[20] Zhou YF, Haynes RJ. Removal of $\mathrm{Pb}(\mathrm{II}), \mathrm{Cr}(\mathrm{III})$ and $\mathrm{Cr}$ (VI) from aqueous solutions using alum-derived water treatment sludge. Water Air Soil Pollut. 2011;215:631-643. DOI: 10.1007/s11270-010-0505-y.

[21] Lai JY, Liu JC. Co-conditioning and dewatering of alum sludge and waste activated sludge. Water Sci Technol. 2004;50(9):41-48.

[22] Hegazy BE, Fouad HA, Hassanain AM. Incorporation of water sludge, silica fume, and rice husk ash in brick making. Adv Environ Res. 2012;1(1):83-96. DOI: 10.1.1.665.8293.

[23] Kizinievic O, Zurauskiene R, Kizinievic V, Zurauskas R. Utilisation of sludge waste from water treatment for ceramic products. Constr Build Mater. 2013;41:464-473. DOI: 10.1016/j.conbuildmat.2012.12.041.

[24] Dayton EA, Basta NT. Characterization of drinking water treatment residuals for use as a soil substitute. Water Environ Res. 2001;73(1):52-57. DOI: 10.2175/106143001X138688.

[25] Rigby H, Pritchard D, Collins D, Walton K, Penney N. The use of alum sludge to improve cereal production on a nutrient-deficient soil. Environ Technol. 2013;34:1359-1368. DOI: 10.1080/09593330.2012.747037.

[26] Husillos Rodrguez N, Martnez-Ramrez S, Blanco-Varela MT, Guillem M, Puig J, Larrotcha E, et al. Evaluation of spray-dried sludge from drinking water treatment plants as a prime material for clinker manufacture. Cem Concr Compos. 2011;33:267-275. DOI: 10.1016/j.cemconcomp.2010.10.020.

[27] Kayranlı B. Adsorption of textile dyes onto iron based waterworks sludge from aqueous solution; isotherm, kinetic and thermodynamic study. Chem Eng J. 2011;173:782-791. DOI: doi.org/10.1016/j.cej.2011.08.051. 
[28] Macek-Kamińska K, Stemplewski S. Application of neural networks in diagnostics of chemical compounds based on their infrared spectra. Ecol Chem Eng S. 2017;24(1):107-118. DOI: 10.1515/eces-2017-0008.

[29] Chen B, Zhou D, Zhu L. Transitional adsorption and partition of nonpolar and polar aromatic contaminants by biochars of pine needles with different pyrolytic temperatures. Environ Sci Technol. 2008;42(14):5137-5143. DOI: 10.1021/es8002684.

[30] Ardejani FD, Badii K, Yousefi Limaee N, Shafaei SZ, Mirhabibi AR. Adsorption of Direct Red 80 dye from aqueous solution onto almond shells: Effect of $\mathrm{pH}$, initial concentration and shell type. J Hazard Mater. 2008;151:730-737. DOI: 10.1016/j.jhazmat.2007.06.048.

[31] Agrawal A, Sahu KK, Pandey BD. Removal of zinc from aqueous solutions using sea nodule residue. Colloids Surf A: Phys Eng Aspects. 2004;237(1-3):133-140. DOI: 10.1016/j.colsurfa.2004.01.034.

[32] Yıldız S. Kinetic and isotherm analysis of $\mathrm{Cu}$ (II) adsorption onto almond shell (Prunus dulcis). Ecol Chem Eng S. 2017;24(1):87-106. DOI: 10.1515/eces-2017-0007.

[33] Yildiz S. Artificial Neural Network (ANN) methods for modeling of $\mathrm{Zn}$ (II) adsorption in batch process. Korean J Chem Eng. 2017;34(9):2423-2434. DOI: 10.1007/s11814-017-0157-3.

[34] Munagapati VS, Kim DS. Equilibrium isotherms, kinetics, and thermodynamics studies for congo red adsorption using calcium alginate beads impregnated with nano-goethite. Eco Environ Saf. 2017;141:226-234. DOI: 10.1016/j.ecoenv.2017.03.036.

[35] Anitha T, Senthil Kumar P, Sathish Kumar K, Sriram K, Feroze Ahmed J. Biosorption of lead(II) ions onto nano-sized chitosan particle blended polyvinyl alcohol (PVA): adsorption isotherms, kinetics and equilibrium studies. Desalin Water Treat. 2016;57:13711-13721. DOI: 10.1080/19443994.2015.1061951.

[36] Gautama SB, Vaishyab RC, Devnania GL, Mathurc AK. Adsorption of As(III) from aqueous solutions by iron-impregnated quartz, lignite, and silica sand: kinetic study and equilibrium isotherm analysis. Desalin Water Treat. 2014;52:3178-3190. DOI: 10.1080/19443994.2013.797182.

[37] Yang S, Li J, Lu Y, Chen Y, Wang X. Sorption of Ni(II) on GMZ bentonite: effects of pH, ionic strength, foreign ions, humic acid and temperature. Appl Radiat Isot. 2009;67:1600-1608. DOI: 10.1016/j.apradiso.2009.03.118

[38] Liu ZR, Zhou SQ. Adsorption of copper and nickel on Na-bentonite. Process Saf Environ Prot. 2010;88:62-66.

[39] Song X, Wang S, Chen L, Zhang M, Dong Y. Effect of pH, ionic strength and temperature on the sorption of radionickel on Na-montmorillonite. Appl Radiat Isot. 2009;67:1007-1012. DOI: 10.1016/j.apradiso.2009.02.085.

[40] Abollino O, Giacomino A, Malandrino M, Mentasti E. Interaction of metal ions with montmorillonite and vermiculite. Appl Clay Sci. 2008;38:227-236. DOI: 10.1016/j.clay.2007.04.002.

[41] Vieira MGA, Neto AFA, Gimenes ML, da Silva MGC. Sorption kinetics and equilibrium for the removal of nickel ions from aqueous phase on calcined Bofe bentonite clay. J Hazard Mater. 2010;177:362-371. DOI: 10.1016/j.jhazmat.2009.12.040.

[42] Paul ML, Samuel J, Chandrasekaran N, Mukherjee A. Comparative kinetics, equilibrium, thermodynamic and mechanistic studies on biosorption of hexavalent chromium by live and heat killed biomass of acinetobacter junii VITSUKMW2, an indigenous chromite mine isolate. Chem Eng J. 2012;187:104-113. DOI: 10.1016/j.cej.2012.01.106.

[43] Rafati L, Ehrampoush MH, Rafati AA, Mokhtari M, Mahvi AH. Modeling of adsorption kinetic and equilibrium isotherms of naproxen onto functionalized nano-clay composite adsorbent. $\mathrm{J}$ Molecular Liquids. 2016;224:832-841. DOI: 10.1016/j.molliq.2016.10.059.

[44] Daneshvar E, Kousha M, Sohrabi MS, Khataee A, Converti A. Biosorption of three acid dyes by the brown macroalga Stoechospermum marginatum: Isotherm, kinetic and thermodynamic studies. Chem Eng J. 2012;195-196:297-306. DOI: 10.1016/j.cej.2012.04.074.

[45] Saini AS, Melo JS. Biosorption of uranium by melanin: Kinetic, equilibrium and thermodynamic studies. Bioresour Technol. 2013;149:155-162. DOI: 10.1016/j.biortech.2013.09.034.

[46] Zhiwei N, Qiaohui F, Wenhua W, Junzheng X, Lei C, Wangsuo W. Effect of pH, ionic strength and humic acid on the sorption of uranium(VI) to attapulgite. Appl Radiat Isot. 2009;67: 1582-1590. DOI: 10.1016/j.apradiso.2009.03.113.

[47] Argun ME, Dursun Ş, Özdemir C, Karataş M. Heavy metal adsorption by modified oak sawdust: Thermodynamics and kinetics. J Hazard Mater. 2007;141(1):77-85. DOI: 10.1016/j.jhazmat.2006.06.095

[48] Lagergren S. About the theory of so called adsorption of soluble substances. Ksver Veterskapsakad Handl. 1898:24, 16.

[49] Ho YS, McKay G. Pseudo-second-order model for sorption processes. Process Biochem. 1999;34:451-465. DOI: 10.1016/S0032-9592(98)00112-5.

[50] Ilyas M, Khan N, Sultana Q. Thermodynamic and kinetic studies of chromium(VI) adsorption by sawdust activated carbon. J Chem Soc Pak. 2014;36(6):1003-1012. 
[51] Namasivayam C, Kavitha D. Adsorptive removal of 2-chlorophenol by low-cost coir pith carbon. J Hazard Mater. 2003;98:257-274. DOI: 10.1016/S0304-3894(03)00006-2.

[52] Cardoso NF, Lima EC, Royer B, Bach MV, Dotto GL, Pinto LAA, et al. Comparison of Spirulina platensis microalgae and commercial activated carbon as adsorbents for the removal of reactive red 120 dye from aqueous effluents. J Hazard Mater. 2012;241-242:146-153. DOI: 10.1016/j.jhazmat.2012.09.026.

[53] Namasivayam C, Sureshkumar MV. Removal of chromium(VI) from water and wastewater using surfactant modified coconut coir pith as a biosorbent. Bioresour Technol. 2008;99(7):2218-2225. DOI: 10.1016/j.biortech.2007.05.023.

[54] Ijagbemi CO, Baek MH, Kim DS. Adsorptive performance of un-calcined sodium exchanged and acid modified montmorillonite for $\mathrm{Ni}^{2+}$ removal: equilibrium, kinetics, thermodynamics and regeneration studies. J Hazard Mater. 2010;174:746-755. DOI: 10.1016/j.jhazmat.2009.09.115.

[55] Katsou E, Malamis S, Haralambous KJ, Loizidou M. Use of ultrafiltration membranes and aluminosilicate minerals for nickel removal from industrial wastewater. J Membr Sci. 2010;360:234-249. DOI: 10.1016/j.memsci.2010.05.020.

[56] Zou W, Han R, Chen Z. Kinetic study of adsorption of $\mathrm{Cu}(\mathrm{II})$ and $\mathrm{Pb}$ (II) from aqueous solutions using manganese oxide coated zeolite in batch mode. Colloids Surf. A: Physicochem Eng Asp. 2006;279:238-246. DOI: 10.1016/j.colsurfa.2006.01.008.

[57] Vieira MGA, Almeida Neto AF, Gimenes ML, da Silva MGC. Sorption kinetics and equilibrium for the removal of nickel ions from aqueous phase on calcined Bofe bentonite clay. J Hazard Mater. 2010;177:362-371. DOI: 10.1016/j.jhazmat.2009.12.040.

[58] Wierzba S, Rajfur M, Nabrdalik M, Klos A. The application of electroanalytical methods to determine affinity series of metal cations for functional biosorbent groups. J Elect Chem. 2018;809:8-13. DOI: 10.1016/j.jelechem.2017.12.037.

[59] Keane MA. The removal of copper and nickel from aqueous solution using $\mathrm{Y}$ zeolite ion exchangers. Colloids Surf. A: Physicochem Eng Asp. 1998;138:11-20. DOI: 10.1016/S0927-7757(97)00078-2.

[60] Inglezakis VJ, Zorpas AA, Loizidou MD, Grigoropoulou HP. The effect of competitive cations and anions on ion exchange of heavy metals. Sep Purif Technol. 2005;46:202-207. DOI: 10.1016/j.seppur.2005.05.008.

[61] Abollino O, Giacomino A, Malandrino M, Mentasti E. Interaction of metal ions with montmorillonite and vermiculite. Appl Clay Sci. 2008;38:227-236. DOI: 10.1016/j.clay.2007.04.002.

[62] Boparai HK, Joseph M, O'Carroll DM. Kinetics and thermodynamics of cadmium ion removal by adsorption onto nano zerovalent iron particles. J Hazard Mater. 2011;186(1):458-465. DOI: 10.1016/j.jhazmat.2010.11.029.

[63] Mckay G, Blair HS, Gardner JR. Adsorption of dyes on chitin. I. Equilibrium studies. J App Polymer Sci. 1982;27(8):3043-3057. DOI: 10.1002/app.1982.070270827.

[64] Abd El-Latif M, Elkady M. Equilibrium isotherms for harmful ions sorption using nano zirconium vanadate ion exchanger. Desalination. 2010;255:21-43. DOI: 10.1016/j.desal.2010.01.020.

[65] Yang CH. Statistical mechanical study on the Freundlich isotherm equation. J Colloid Inter Sci. 1998;208:379-387. DOI: 10.1006/jcis.1998.5843.

[66] Ali RM, Hamad HA, Hussein MM, Malash GH. Potential of using green adsorbent of heavy metal removal fromaqueous solutions: Adsorption kinetics, isotherm, thermodynamic, mechanism and economic analysis. Ecol Eng. 2016;91:317-332. DOI: 10.1016/j.ecoleng.2016.03.015.

[67] Ostroski IC, Barros MASD, Silva EA, Dantas JH, Arroyo PA, Lima OCMA. A comparative study for the ion exchange of $\mathrm{Fe}(\mathrm{III})$ and $\mathrm{Zn}(\mathrm{II})$ on zeolite NaY. J Hazard Mater. 2009;161:1404-1412. DOI: 10.1016/j.jhazmat.2008.04.111.

[68] Sprynskyy M, Buszewski B, Terzyk AP, Namieśnik J. Study of the selection mechanism of heavy metal $\left(\mathrm{Pb}^{2+}, \mathrm{Cu}^{2+}, \mathrm{Ni}^{2+}\right.$, and $\left.\mathrm{Cd}^{2+}\right)$ adsorption on clinoptilolite. J Colloid Inter Sci. 2006;304:21-28. DOI: 10.1016/j.jcis.2006.07.068.

[69] Liu Y, Liu YJ. Biosorption isotherms, kinetics and thermodynamics. Sep Purif Technol. 2008;61:229-242. DOI: 10.1016/j.seppur.2007.10.002.

[70] Hasany SM, Chaudhary MH. Sorption potential of Hare River sand for the removal of antimony from acidic aqueous solution. App Radiat Isot. 1996;47:467-471. DOI: 10.1016/0969-8043(95)00310-X.

[71] Onyang MS, Kojima Y, Aoyi O, Bernardo EC, Matsuda H. Adsorption equilibrium modeling and solution chemistry dependence of fluoride removal from water by trivalent-cation-exchanged zeolite F-9. J Colloid Inter Sci. 2004;279:341-350. DOI: 10.1016/j.jcis.2004.06.038.

[72] Febrianto J, Kosasih AN, Sunarso J, Ju YH, Indraswati N, Ismadji S. Equilibrium and kinetic studies in adsorption of heavy metals using biosorbent: A summary of recent studies. J Hazard Mater. 2009;162:616-645. DOI: 10.1016/j.jhazmat.2008.06.042.

[73] Winzor DJ, Jackson CM. Interpretation of the temperature dependence of equilibrium and rate constants. J Molec Recog. 2006;19(5):389-407. DOI: 10.1002/jmr.799. 
[74] Anastasia V, Penkova SFA, Acquah MP, Sokolova ME, Dmitrenko AMT. Polyvinyl alcohol membranes modified by low-hydroxylated fullerenol C60(OH)12. J Membrane Sci. 2015;491:22-27. DOI: 10.1016/j.memsci.2015.05.011.

[75] Ai T, Jiang XJ, Yu HM, Xu HB, Pan DW, Liu QY. Equilibrium, kinetic and mechanism studies on the biosorption of $\mathrm{Cu}^{2+}$ and $\mathrm{Ni}^{2+}$ by sulfur-modified bamboo powder. Korean $\mathrm{J}$ Chem Eng. 2015;32:342-349.

[76] Gupta SS, Bhattacharyya KG. Adsorption of Ni(II) on clays. J Colloid Inter Sci. 2006;295:21-32. DOI: 10.1016/j.jcis.2005.07.073.

[77] Moreno-Piraján JC, Garcia-Cuello VS, Giraldo L. The removal and kinetic study of Mn, Fe, Ni and Cu ions from wastewater onto activated carbon from coconut shells. Adsorption. 2011;17:505-514. DOI: 10.1007/s10450-010-9311-5.

[78] Osman HE, Badwy RK, Ahmad HF. Usage of some agricultural by-products in the removal of some heavy metals from industrial wastewater. J Phytol. 2010;2:51-62.

[79] Rozaini CA, Jain K, Oo CW, Tan KW, Tan LS, Azraa A, et al. Optimization of nickel and copper ions removal by modified mangrove barks. Int J Chem Eng Appl. 2010;1(1):84-89.

[80] Tabaraki R, Nateghi A. Multimetal adsorption modeling of $\mathrm{Zn}^{2+}, \mathrm{Cu}^{2+}$ and $\mathrm{Ni}^{2+}$ by Sargassum ilicifolium. Ecol Eng. 2014;71:197-205. DOI: 10.1016/j.ecoleng.2014.07.031.

[81] Álvarez-Ayuso E, García-Sánchez A, Querol X. Purification of metal electroplating waste waters using zeolites. Water Res. 2003;37:4855-4862. DOI: 10.1016/j.watres.2003.08.009.

[82] Bhattacharyya KG, Gupta SS. Uptake of Ni(II) ions from aqueous solution by kaolinite and montmorillonite: influence of acid activation of the clays. Sep Sci Technol. 2008;43:3221-3250. DOI: 10.1080/01496390802219638.

[83] Bhattacharyya KG, Gupta SS. Influence of acid activation on adsorption of $\mathrm{Ni}$ (II) and $\mathrm{Cu}$ (II) on kaolinite and montmorillonite: kinetic and thermodynamic study. Chem Eng J. 2008;136:1-13. DOI: 10.1016/j.cej.2007.03.005.

[84] Blais JF, Shen S, Meunier N, Tyagi R.D. Comparison of natural adsorbents for metal removal from acidic effluent. Environ Technol. 2003;24:205-215. DOI: 10.1080/09593330309385552.

[85] Hui KS, Chao CYH, Kot SC. Removal of mixed heavy metal ions in wastewater by zeolite 4A and residual products from recycled coal fly ash. J Hazard Mater. 2005;127:89-101. DOI: 10.1016/j.jhazmat.2005.06.027. 